\title{
Impacts of land-use and land-cover change on stream hydrochemistry in the Cerrado and Amazon biomes
}

Article

Accepted Version

Creative Commons: Attribution-Noncommercial-No Derivative Works 4.0

Nobrega, R. L. B., Guzha, A. C., Lamparter, G., Amorim, R. S. S., Couto, E. G., Hughes, H. J., Jungkunst, H. F. and Gerhard, G. (2018) Impacts of land-use and land-cover change on stream hydrochemistry in the Cerrado and Amazon biomes. Science of the Total Environment, 635. pp. 259-274. ISSN 0048-9697 doi: https://doi.org/10.1016/j.scitotenv.2018.03.356 Available at https://centaur.reading.ac.uk/76653/

It is advisable to refer to the publisher's version if you intend to cite from the work. See Guidance on citing.

Published version at: https://www.sciencedirect.com/science/article/pii/S0048969718311161

To link to this article DOI: http://dx.doi.org/10.1016/j.scitotenv.2018.03.356

Publisher: Elsevier

All outputs in CentAUR are protected by Intellectual Property Rights law, including copyright law. Copyright and IPR is retained by the creators or other copyright holders. Terms and conditions for use of this material are defined in the End User Agreement. 


\section{CentAUR}

Central Archive at the University of Reading

Reading's research outputs online 


\section{Impacts of land-use and land-cover change on stream hydrochemistry in the Cerrado and Amazon biomes}

Rodolfo L. B. Nóbrega a, ${ }^{\star}$, Alphonce C. Guzha ${ }^{b}$, Gabriele Lampartera, Ricardo S. S. Amorimc, Eduardo G. Couto ${ }^{c}$, Harold J. Hughes ${ }^{a}$, Hermann F. Jungkunst ${ }^{d}$, Gerhard Gerold ${ }^{a}$

a University of Goettingen, Faculty of Geosciences and Geography, Goettingen, Germany.

b U.S.D.A. Forest Service, International Programs, c/o CIFOR, World Agroforestry Center, Nairobi, Kenya.

${ }^{c}$ Federal University of Mato Grosso, Department of Soil and Agricultural Engineering, Cuiabá, Brazil.

d University of Koblenz-Landau, Institute for Environmental Sciences, Geoecology \& Physical Geography, Landau, Germany.

* Corresponding author at: University of Reading, Whiteknights, Department of Geography and Environmental Science, Reading, United Kingdom, r.nobrega@reading.ac.uk. 
1 Abstract - Studies on the impacts of land-use and land-cover change on stream

2 hydrochemistry in active deforestation zones of the Amazon agricultural frontier are

3 limited and have often used low-temporal-resolution datasets. Moreover, these impacts

4 are not concurrently assessed in well-established agricultural areas and new

5 deforestations hotspots. We aimed to identify these impacts using an experimental setup

6 to collect high-temporal-resolution hydrological and hydrochemical data in two pairs of

7 low-order streams in catchments under contrasting land use and land cover (native

8 vegetation vs. pasture) in the Amazon and Cerrado biomes. Our results indicate that the

9 conversion of natural landscapes to pastures increases carbon and nutrient fluxes via

10 streamflow in both biomes. These changes were the greatest in total inorganic carbon in

11 the Amazon and in potassium in the Cerrado, representing a 5.0- and 5.5-fold increase

12 in the fluxes of each biome, respectively. We found that stormflow, which is often

13 neglected in studies on stream hydrochemistry in the tropics, plays a substantial role in

14 the carbon and nutrient fluxes, especially in the Amazon biome, as its contributions to

15 hydrochemical fluxes are mostly greater than the volumetric contribution to the total

16 streamflow. These findings demonstrate that assessments of the impacts of deforestation

17 in the Amazon and Cerrado biomes should also take into account rapid hydrological

18 pathways; however, this can only be achieved through collection of high-temporal-

19 resolution data.

20 Keywords: carbon, nutrients, agricultural frontier, rainforest, savanna, deforestation.

21 1. Introduction

22 It has been widely acknowledged that surface conditions of terrestrial ecosystems have

23 strong synergies with hydrological processes (Cuo et al., 2013; Neill et al., 2008; Recha 
1 et al., 2012; Rodriguez et al., 2010). These processes are often influenced by land-use

2 practices, which, in turn, can change catchment responses, such as stream

3 hydrochemistry (Crossman et al., 2014; El-Khoury et al., 2015; Oni et al., 2014; Öztürk et

4 al., 2013; Salemi et al., 2013; Vogt et al., 2015). Because of large-scale environmental

5 impacts resulting from the conversion of native habitats into agricultural frontiers

6 (Schiesari et al., 2013), it is fundamental to comprehend how land-use and land-cover

7 (LULC) change influences hydrochemical processes in pristine catchments undergoing

8 anthropogenic changes (Jordan et al., 1997; Neill et al., 2013). Therefore, studies have

9 often focused on regions under intensive forest degradation due to agricultural expansion,

10 such as the Brazilian Amazon, to assess the impacts of LULC change on stream

11 hydrochemistry (Dias et al., 2015; Figueiredo et al., 2010b; Germer et al., 2009; Neill et

12 al., 2011; Recha et al., 2013; Williams and Melack, 1997).

13 The Amazonian agricultural frontier (AAF), also known as the arc of deforestation, 14 extends from the eastern to the southwestern edge of the Brazilian Amazon, comprising 15 a wide area along the Amazon-Cerrado ecotone (Do Vale et al., 2015; Durieux, 2003; 16 Silva et al., 2013). Deforestation in this region has taken place due to agricultural 17 expansion during recent decades, and represents most of the deforestation of the AAF 18 (Brannstrom et al., 2008; Fearnside, 2001; Riskin et al., 2013; Tollefson, 2015). This ongoing change threatens the services provided by native ecosystems, such as the water quantity and quality that sustain aquatic biodiversity and mitigates eutrophication of water

21 bodies (Coe et al., 2013; Davidson et al., 2012; Neary, 2016; Penaluna et al., 2017).

22 However, despite the important contribution of several research initiatives (e.g., Andreae 23 et al., 2015; Lahsen and Nobre, 2007; Satinsky et al., 2014), an understanding of the 
1 influence of LULC change on water resources in the Brazilian Amazon region remains

2 limited. Furthermore, the Cerrado biome, where most of the AAF deforestation has occurred (Klink and Machado, 2005), is often not integrated in studies regarding Amazon

4 deforestation; consequently, it is one of the lesser-studied regions in terms of the 5 environmental effects of LULC change resulting from agricultural expansion (Hunke et 6 al., 2015a; Jepson et al., 2010; Oliveira et al., 2015) despite being a biodiversity hotspot

7 for conservation comprised of dry forests, woodland savannas and grasslands (Spera et 8 al., 2016; Strassburg et al., 2017). The conversion of native vegetation to crops and 9 pastures has removed ca. $50 \%$ of the original 2 million $\mathrm{km}^{2}$ in the Cerrado, which is 10 greater than the forest loss in the Amazon biome (Klink and Machado, 2005; Lambin et 11 al., 2013).

12 The negative impacts on water quality due to LULC change are reported to be a result of 13 interrelated processes (i.e., changes in vegetation, soil and hydrology) that negatively 14 disturbs its land capability, which is the ability of the land to sustain its use (Valle et al., 15 2014; Valle Junior et al., 2015). On the AAF, soil and hydrological changes have been linked to forest clearing and conversion to pastures (Neill et al., 2008; Zimmermann et al., 2006). Indeed, LULC change on the AAF has been primarily driven by the expansion of pastures (Armenteras et al., 2013; Schierhorn et al., 2016). After some years, these pastures are often either replaced by cash crop systems (Barona et al., 2010; Cohn et 20 al., 2016) or abandoned due to decreased grass productivity, ultimately reaching 21 advanced stages of degradation (Davidson et al., 2012). Variations in nutrient input into 22 rivers caused by LULC change on the AAF deserve particular attention because of their potential impact on both biogeochemistry and aquatic ecosystem functioning (Neill et al., 
1 2011). Even though rain and dry forests account for ca. $60 \%$ of the net primary production

2 of global terrestrial ecosystems (Grace et al., 2006; Potter et al., 2012), the effects of the

3 impacts of LULC change in these systems are not well studied as they are for other

4 regions of the world (Luke et al., 2017).

5 The initial effects of LULC change on the hydrochemistry of rivers have often been

6 observed in low-order streams (Hope et al., 2004; Neill et al., 2001; Richey et al., 1997),

7 which connect the terrestrial environment to large rivers and integrate environmental

8 processes, especially landscapes undergoing change (Alexander et al., 2000; Moreira-

9 Turcq et al., 2003). These characteristics qualify small streams as sensitive indicators of

10 changes in ecosystems due to LULC change and allow their use as important references

11 in carbon exportation studies and as early warning systems for ecological change

12 (Christophersen et al., 1994). Although many studies have evaluated the dynamics of

13 carbon and nutrients in streams in several regions of the world (e.g. Southeastern USA

14 (Marchman et al., 2015), subtropical China (Yan et al., 2015), Germany (Strohmeier et

15 al., 2013) and Canada (Jollymore et al., 2012)), studies of carbon export dynamics in low-

16 order tropical catchments are still scarce (de Paula et al., 2016). There is increasing

17 research interest in high-temporal-resolution data collection in low-order fluvial systems

18 that should also be taken into account in hydrochemistry studies (Hughes et al., 2005;

19 Richey et al., 2011; Wohl et al., 2012) due to their importance to the global carbon 20 dynamics (Bass et al., 2014).

21 The dynamics of stream hydrochemistry that have remained largely invisible due to the

22 monitoring schemes that only consider weekly or monthly sampling (Kirchner and Neal,

23 2013), have been gradually unveiled due to approaches that use subdaily sampling 
1 intervals (Tang et al., 2008). However, the high-frequency water sampling approach that

2 has been shown to be useful for these studies in temperate regions (Clark et al., 2007)

3 has been discredited in tropical regions (Chaussê et al., 2016). Moreover, findings in

4 Amazonian headwater streams that have used subhourly sampling routines have found

5 that the conversion of forests to fertilized agricultural lands changed neither the stream

6 water chemistry nor nutrient output per unit of catchment area (Neill et al., 2017; Riskin

7 et al., 2017).

8 Our study aims to identify the differences in stream carbon and nutrient (CAN)

9 concentrations and output fluxes during prevalent baseflow and stormflow conditions in

10 headwater catchments under contrasting LULC (native vegetation vs. pasture), thereby

11 contributing to the understanding of CAN drivers in low-order streams on the AAF. Our

12 hypothesis is that LULC change is impacting stream hydrochemistry in active

13 deforestation zones of the Amazon and Cerrado biomes, with the stormflow, which is

14 often neglected in studies in these regions, as a substantial contributor to the total CAN 15 fluxes.

17 2. Study area

18 Our study follows the space-for-time substitution approach to compare adjacent 19 headwater catchments with different LULC but with similar characteristics, i.e. slope, 20 geology, soils, aspect and climate (Troch et al., 2015). Studies have often used this 21 approach to understand the effects of vegetation and land use on hydrological responses 22 in small catchments (Brown et al., 2005; de Moraes et al., 2006; Germer et al., 2010; 23 Muñoz-Villers and McDonnell, 2013; Ogden et al., 2013; Roa-García et al., 2011). It has 
1 also been applied to compare the impacts of LULC change on stream hydrochemistry of

2 contrasting catchments (Sun et al., 2013; Zhao et al., 2010).

3 We used two pairs of microcatchments on the AAF (Fig. 1) with contrasting LULC. Each

4 pair of catchments consists of a catchment with predominantly native vegetation land

5 cover and a catchment with predominantly pasture land cover used for extensive cattle

6 ranching. One pair of catchments is in the municipality of Novo Progresso (Brazilian state

7 of Pará), which is a hotspot of deforestation in the Amazon biome (Pinheiro et al., 2016;

8 Rufin et al., 2015), and the other pair is in the municipality of Campo Verde (Brazilian

9 state of Mato Grosso), which is a region that has been massively deforested since the

101970 s and is now a well-established agro-industrial area in the Cerrado biome. The

11 catchments in Novo Progresso, hereafter referred to as the Amazonian catchments, are

12 in the Jamanxim River watershed, which is one of the major southern subtributaries of

13 the Amazon River. The catchments in Campo Verde, hereafter referred to as the Cerrado

14 catchments, are in the das Mortes River watershed, the principal tributary of the Araguaia

15 River.

16 The Amazonian catchments consist of one catchment covered with evergreen rainforest,

17 with sings of logging and tree regrowth (AFOR), and another catchment covered by degraded pasture grassland (APAS). The AFOR catchment is the only catchment that is drained by a non-perennial stream; it typically flows from November to July. The Cerrado 20 catchments are approximately $200 \mathrm{~m}$ apart, consisting of one catchment covered with 21 cerrado sensu stricto vegetation (CCER) and another catchment covered by pasture 22 grassland with signs of degradation (CPAS). The cerrado sensu stricto is characterized 23 as dense orchard-like vegetation consisting of many species of grasses and sedges, and 
1 mixed with a great diversity of forbs and trees with an average height of $6 \mathrm{~m}$ (Canadell et

2 al., 1996; Furley, 1999; Goodland, 1971; Goodland and Pollard, 1973; Ratter et al., 1997).

3 The APAS catchment was established in 1984, and the CPAS catchment was established

4 in 1994. Both pasture catchments are mostly covered by grasses (Brachiaria grass

5 species) that exhibit low productivity rates. Lime (calcium carbonate, $\mathrm{CaCO}_{3}$ ) was applied

6 in the pasture catchments several years before the study period. The climate in the

7 Amazonian catchments is humid tropical, with a mean precipitation of ca. 1,900 mm $\mathrm{yr}^{-1}$,

8 and a tropical wet and dry climate in the Cerrado catchments, with a mean precipitation

9 of ca. 1,700 mm yr ${ }^{-1}$. More details regarding the climate, soils, morphology and hydrology

10 of this region can be found in Lamparter et al. (2018), and Guzha et al. (2015) and in

11 Nóbrega et al. (2017) for the Amazonian and Cerrado catchments, respectively. For

12 clarity and to simultaneously compare the contrasting catchments within their respective

13 biomes, we use the term native vegetation catchments to refer to the AFOR and CCER 14 catchments, and the term pasture catchments to refer to the APAS and CPAS

15 catchments, whose main characteristics are shown in Table 1. We instrumented these

16 catchments during the dry season of 2012 and continuously monitored them from October 17 of 2012 until the September of 2014.

\section{Methods}

\subsection{Soil physical and chemical properties}

21 To support our findings related to CAN stream dynamics, we used evidence from soil

22 chemical and textural analyses. We collected disturbed soil samples from the topsoil (0-

$2310 \mathrm{~cm}$ soil depth), from 6 to 8 approximately equally spaced points along a topographic 
1 sequence of landscape positions from a gently sloping upper plateau, to a middle slope

2 and a low-gradient valley bottom on the basis of digital elevation models (DEMs) derived

3 from a topographic survey in each catchment. The topsoil of these catchments was

4 chosen because it has a strong synergy with the surface waters and it is the soil layer

5 under most direct influence of the LULC change (Lamparter et al., 2018). The topographic

6 survey conducted in the Cerrado catchments is described in detail in Nóbrega et al.

7 (2017); the described procedure was also used for the Amazonian catchments. We

8 analyzed these soil samples to determine $\mathrm{pH}$, total carbon (TC), total nitrogen (TN),

9 aluminum $(\mathrm{Al})$, calcium $(\mathrm{Ca})$, iron $(\mathrm{Fe})$, potassium $(\mathrm{K})$, magnesium $(\mathrm{Mg})$, sodium $(\mathrm{Na})$,

10 phosphorus $(\mathrm{P})$, sulfur $(\mathrm{S})$ and particle size distribution. The particle size distribution was

11 measured using the Köhn pipette method (DIN ISO 11277:2002-08, 2002). pH was

12 measured using the potentiometric method (inoLAB ${ }^{\circledR} \mathrm{pH}$ Level 2, Wissenschaftlich-

13 Technische Werkstätten $\mathrm{GmbH}$ ). TC and TN were quantified using an elemental analysis

14 method (TruSpec ${ }^{\circledR} \mathrm{CHN}$, LECO Instrumente $\mathrm{GmbH}$ ). For chemical analysis, a total

15 digestion of $100-150 \mathrm{mg}$ of soil was created with $\mathrm{HClO}_{4}$, $\mathrm{HF}$ and $\mathrm{HNO}_{3}$ in $30-\mathrm{mL}$

16 polytetrafluoroethylene (PTFE) vessels (Pressure Digestion System DAS 30, PicoTrace

$17 \mathrm{GmbH}$ ), and chemical concentrations were determined using inductively coupled plasma

18 atomic emission spectroscopy (ICP-OES, Optima 4300 TM DV for the Cerrado catchments

19 and ICP-OES Optima $5300^{\mathrm{TM}}$ for the Amazonian catchments, PerkinElmer, Germany).

20 Chemical analyses of soils from the Amazonian catchments were conducted at the

21 Laboratory of the Department of Plant Ecology and Ecosystems Research and those of

22 the Cerrado catchments were conducted at the Laboratory of the Department of

23 Landscape Ecology, both at the University of Goettingen, Germany. 
$2 \quad 3.2$ Water-sampling design and analysis

3 An automatic water sampler $\left(\mathrm{BL} 2000^{\circledR}\right.$, Hach-Lange $\left.\mathrm{GmbH}\right)$ was installed at the outlet of

4 each catchment to collect stream water ca. $20 \mathrm{~cm}$ below the water surface and $2-4 \mathrm{~m}$

5 upstream from the catchment weir. The sampling procedure was simultaneously based

6 on both time intervals and water-level variations to characterize the streamflow

7 hydrochemistry during baseflow- and stormflow-prevailing conditions, respectively. The

8 time sampling routine was based on filling a 1-L sample bottle over $1-3$ days using an

9 extraction of $200 \mathrm{~mL}$ from the stream at equal intervals. The stormflow sampling was

10 determined suing a subhourly routine activated by water-level increase and detected by

11 a pressure bell switch (FD-01, Profimess $\mathrm{GmbH}$ ). The pressure bell switches and the

12 automatic samplers were calibrated throughout the year according to the water-level

13 variation to maximize the coverage of the catchment stormflows, which considered the

14 time of every sampling procedure and its respective hydrograph.

15 The samples from the Cerrado catchments were transported to the Ecofisiologia Vegetal 16 Laboratory (EVL) at the Federal University of Mato Grosso (UFMT) in Cuiabá, Mato

17 Grosso. The samples from the Amazonian catchments were also brought to this

18 laboratory with prior preparation at a field facility ca. $5 \mathrm{~km}$ from the catchments and stored 19 in light-free freezers until their transportation to the EVL. Transport of all water samples

20 to the EVL was made using light-free coolers packed with ice. After transportation, the 21 water in each bottle was used to fill two 50-mL aliquots in high-density polyethylene

22 bottles prewashed with deionized water. One aliquot was used for the analysis of TC, 23 total organic carbon (TOC), total inorganic carbon (TIC) and TN, and the other was filtered 
1 with pre-ashed glass fiber filters $(0.7-\mu \mathrm{m}$ nominal pore size, Whatman GF/F) prewashed with $20 \mathrm{~mL}$ of water sample for the remaining analyses. The samples were then frozen and shipped in Styrofoam coolers for analysis at the Laboratory of the Department of

4 Landscape Ecology, University of Goettingen, Germany (total travel time of ca. $22 \mathrm{~h}$ ).

5 TC, TIC, TOC, total dissolved carbon (DC), dissolved inorganic carbon (DIC) and DOC 6 contents were determined using high-temperature catalytic oxidation (TC-Analyzer,

7 DIMATOC $100(\mathrm{R})$, Dimatec $\mathrm{GmbH})$. TN and $\mathrm{DN}$ were quantified using the 8 chemiluminescence detection method (DIMA_N module (CLD), Dimatec $\mathrm{GmbH}$ ). Fluorine $9(\mathrm{~F})$, chlorine $(\mathrm{Cl})$, nitrate $\left(\mathrm{NO}_{3}\right)$ and sulfate $\left(\mathrm{SO}_{4}\right)$ concentrations were determined using ion chromatography (761 Compact IC, Metrohm, Switzerland). Dissolved Ca, Fe, K, Mg,

$11 \mathrm{Na}, \mathrm{P}$ and $\mathrm{S}$ concentrations were quantified using atomic spectroscopy (ICP-OES, 12 Optima $4300^{\mathrm{TM}}$ DV, PerkinElmer). Prior to the analyses of the dissolved solutes, the water 13 samples were filtered through membrane filters $(0.45-\mu \mathrm{m}$ nominal pore size, cellulose 14 acetate, Sartorius Stedim Biotech $\mathrm{GmbH}$ ). These filters were prewashed with ultrapure 15 water and transferred to high density polyethylene (HDPE) bottles that were prewashed with nitric acid solution (2.6\% $\left.\mathrm{HNO}_{3}\right)$ and rinsed with ultrapure water.

17 For quality control, during the entire study period, approximately $20 \%$ of the water 18 samples were analyzed for DOC within 12 hours after collection using a UV-Vis spectrometric device (spectro::Iyser ${ }^{\mathrm{TM}} \mathrm{UV}-\mathrm{Vis}$, s::can Messtechnik $\mathrm{GmbH}$ ) to cross-check 20 with the final DOC results. This comparison indicated a linear correlation $(r=.96, n=200$, $21 p<.001$, Pearson's correlation), which is considered adequate because of the 22 insignificant differences in DOC estimation by the spectrometric device calibration 23 (Avagyan et al., 2014; Bass et al., 2011). Additionally, a 1-L water sample was manually 
1 collected in an automatic sampler bottle and kept in a separate automatic water sampler

2 unit at the EVL to check DOC fluctuations resulting from the storage of the samples in

3 this instrument. This water sample was analyzed using the spectrometric device up to 8

4 days after sampling, which was the average time interval of the field trips for sample

5 collection. This procedure was conducted during the first wet season (January-May of

6 2013) and did not indicate any significant changes in the DOC concentrations.

\subsection{Streamflow and CAN output fluxes}

9 At the outlet of each catchment, an adjustable weir was installed. During the rainy season,

the weirs were rectangular, whereas a v-notch contraction section was inserted during

11 the dry season. A multiparameter probe (DS 5X, OTT) was installed 2-4 m upstream of

12 each catchment's weir to obtain data on water level at 10 or 15 -min intervals. To quantify

13 catchment discharge (flow rate), we used the standard flow equation (Eq. (1)) based on

14 the Bernoulli equation for the rectangular weir, and the Kindsvater-Shen equation (Eq.

15 (2)) together with calibration adjustment functions (Eqs. (3) and (4)) for the v-notch weir 16 (Shen, 1981), as follows:

$17 \quad Q=\frac{2}{3} C_{d R} b \sqrt{2 g} h^{\frac{3}{2}}$,

$18 Q=\frac{8}{15} C_{e} \sqrt{2 g} \tan \left(\frac{\theta}{2}\right) h_{e}^{\frac{5}{2}}$,

$19 K_{h}=0.001[\theta(1.395 \theta-4.296)+4.135]$,

20

$C_{e}=\theta(0.02286 \theta-0.05734)+0.6115$

21 where $Q$ is the discharge over the weir $\left(m^{3} \mathrm{~s}^{-1}\right) ; C_{d R}$ and $C e$ are the effective

22 dimensionless discharge coefficients for the rectangular and v-notch weirs, respectively; 
$1 \quad b$ is the weir length $(m) ; \theta$ is the angle of the v-notch (radians); $h$ is the upstream head

2 above the crest of the weir $(m)$; $h_{e}$ is the effective head $\left(h+K_{h}\right)$; and $K_{h}$ is the head-

3 adjustment factor. For the Amazonian catchments, we adopted a $C_{d R}$ of 0.62 based on

4 the geometric characteristics of the weirs (Kindsvater and Carter, 1957). For the Cerrado

5 catchments, we conducted discharge calibration measurements using an acoustic digital

6 current meter (ADC, OTT) and estimated $C_{d R}$ values of 0.74 for the CCER catchment and

70.65 for the APAS catchment.

8 We classified the streamflow as base streamflow $\left(\mathrm{S}_{\mathrm{b}}\right)$ and storm streamflow $\left(\mathrm{S}_{\mathrm{s}}\right)$, which

9 represent the total stream discharge during baseflow- and stormflow-prevailing

10 conditions, respectively. $S_{s}$ was computed as the flow change in response to event

11 precipitation and ending at the point separating the stormflow components, i.e. the

12 surface and subsurface stormflow, from the baseflow recession. These flows were

13 determined using a recursive digital filter (Eckhardt, 2005) implemented in the Web GIS-

14 based Hydrograph Analysis Tool (WHAT) for baseflow separation (Lim et al., 2010, 2005).

15 Using this information, we calculated the ratio of $\mathrm{S}_{\mathrm{s}}$ to total streamflow $\left(\mathrm{S}_{\mathrm{t}}\right)$ discharge.

16 The annual CAN stream output fluxes for each catchment were calculated multiplying the

17 annual mean CAN concentration by the respective annual $S_{b}$ and $S_{s}$ volumes (Eqs. 5 and

$186)$ as follows:

$19 F_{T S_{b}}=\frac{C_{S_{b}} \times V_{S_{b}}}{A \times 10^{6}}$,

$20 F_{T S_{S}}=\frac{C_{S S} \times V_{S_{S}}}{A \times 10^{6}}$,

21 where $\mathrm{F}_{\mathrm{TSb}}$ and $\mathrm{F}_{\mathrm{TSs}}$ are, respectively, the annual CAN output fluxes of $\mathrm{S}_{\mathrm{b}}$ and $\mathrm{S}_{\mathrm{s}}$ (kg ha-

$\left.22{ }^{1} \mathrm{yr}^{-1}\right)$; $\mathrm{Csb}_{\mathrm{sb}}$ is the mean CAN concentration in $\mathrm{S}_{\mathrm{b}}\left(\mathrm{mg} \mathrm{L}^{-1}\right)$; $\mathrm{Css}_{\mathrm{s}}$ is the volume-weighted 
1 mean CAN concentration obtained using Eq. $7\left(\mathrm{mg} \mathrm{L}^{-1}\right) ; \mathrm{V}_{\mathrm{Sb}}$ and $\mathrm{V}_{\mathrm{Ss}}$ are the mean annual

$2 S_{b}$ and $S_{s}$ discharges $\left(L y r^{-1}\right)$, respectively; and $A$ is the catchment area (ha).

$3 \quad C_{S S}=\frac{\sum_{j=1}^{m}\left(\sum_{i=1}^{n} \frac{c_{S_{S(i)}}}{n}\right) \times V j}{\sum_{j=1}^{m} V j}$,

4 where $\mathrm{Css}_{(i)}$ is the CAN concentration per $\mathrm{S}_{\mathrm{s}}$ event interval $i$ for the number of event

5 intervals $n\left(\mathrm{mg} \mathrm{L}^{-1}\right)$ and $V_{j}$ is the volume per event $j$ for the number of $S_{s}$ events $m(L)$.

6

7 3.4. Statistical analysis

8 We used principal component analysis (PCA) to identify the most representative 9 hydrochemical parameters causing most of the total variance in $S_{b}$ and $S_{s}$. PCA is 10 commonly used to identify the variables that contain the most information and to provide 11 future data collection criteria in ecological studies (King and Jackson, 1999; Zhang et al., 12 2009). It is useful for the identification of important surface water-quality parameters 13 (Ouyang, 2005; Zeinalzadeh and Rezaei, 2017).

14 We conducted PCAs separately for each biome (Amazon and Cerrado) and flow condition $15\left(\mathrm{~S}_{b}\right.$ and $\left.\mathrm{S}_{\mathrm{s}}\right)$ in order to avoid the dominance of the PCA by the data variance of only one specific region or streamflow condition. We used the Kaiser-Meyer-Olkin (KMO) test

17 (Kaiser, 1974) as a measure of quality control in the PCAs. The KMO test measures the 18 sampling adequacy of each variable for the complete analysis. We only considered CAN parameters with individual $\mathrm{KMO}$ values greater than the bare minimum of .5; therefore 20 we repeated the PCAs, excluding the unacceptable CAN parameters from the analyses, 21 until we obtained acceptable individual KMO results. We applied the orthogonal rotation 22 varimax with Kaiser normalization to the PCAs to maximize the dispersion of loadings 
1 within the factors and considered the results with the most significant components

2 (eigenvalues $>1)$.

3 We used the Kolmogorov-Smirnov test of normality for each dataset to determine the

4 adequate statistical test, i.e., parametric or nonparametric, for comparison of catchments

5 within the same biome. We used the two-sample t-test to compare the soil chemistry and

6 the Mann-Whitney (MW) U-test to compare the CAN concentrations by means of sample

7 ranks to determine whether $S_{b}$ and $S_{s}$ were significantly different between the native

8 vegetation and pasture catchments. Additionally to the MW test, we used Mood's median

9 test, given its robustness for outliers to detect differences in the median. We used the

10 language and environment $R$ ( $R$ Core Team, 2017) and the significance threshold at .05

11 for all statistical analyses.

13 4. Results

$14 \quad 4.1$ Soil physical and chemical properties

15 The soils exhibited textural similarities within each pair of catchments, with mostly sandy 16 clay loams in the Amazonian and loamy sand textures in the Cerrado catchments (Table

17 2). The soil $\mathrm{pH}$ was between 10 to $25 \%$ higher in the pasture catchments, being significantly different $(p<.01)$ between the CCER and CPAS catchments. The soils from

19 all catchments have a high content of $\mathrm{Al}$ and $\mathrm{Fe}$ and low nutrient contents (Table 2). K, $20 \mathrm{Mg}$ and $\mathrm{Mn}$ contents exhibited significant differences $(p<.05)$ between the Amazonian 21 catchments, with higher Mn content in the AFOR than that of the APAS catchment. In the

22 Cerrado catchments, Ca was the only element to exhibit significant differences $(p<.01)$ 23 between the CCER $\left(0.03 \mathrm{~g} \mathrm{~kg}^{-1}\right)$ and CPAS catchments $\left(0.18 \mathrm{~g} \mathrm{~kg}^{-1}\right)$. 


\subsection{Hydrochemistry results}

TOC, DOC, $\mathrm{K}$ and $\mathrm{NO}_{3}$ exhibited the highest mean concentrations $\left(>1 \mathrm{mg} \mathrm{L}^{-1}\right)$ in the Amazonian catchments under both flow conditions. For these catchments, our results indicate low mean streamflow concentrations for $\mathrm{Cl}, \mathrm{SO}_{4}, \mathrm{Na}$, $\mathrm{Ca}$ and $\mathrm{Mg}\left(<0.4 \mathrm{mg} \mathrm{L}^{-1}\right)$. In the Cerrado catchments, $\mathrm{TOC}, \mathrm{DOC}, \mathrm{NO}_{3}$ and $\mathrm{Ca}$ showed the highest mean concentrations. Other elements, such as $\mathrm{Mg}$ and $\mathrm{Na}$, exhibited relatively low concentrations in the CCER catchment. $\mathrm{Fe}, \mathrm{F}, \mathrm{P}, \mathrm{S}$ and $\mathrm{SO}_{4}$ had the lowest concentrations in all catchments, with most values less than the limit of detection (Tables A.1 and A.2).

The varimax rotation applied to the PCA on the water quality parameters exhibited individual KMO values greater than .5 (Table 3). The overall KMO was .70 for $\mathrm{S}_{\mathrm{b}}$ and .63 for the $S_{s}$ PCAs in the Amazonian catchments, and .68 for both the $S_{b}$ and $S_{s}$ PCAs in the Cerrado catchments, which are acceptable values of sampling adequacy for PCA (Kaiser, 1974). Bartlett's test of sphericity for the parameters indicated that correlations between items were sufficiently great for PCA $(p<.001)$. Kaiser's criterion of eigenvalues greater than 1 was met by two components in the $S_{b}$ PCAs and by three components in the stormflow PCAs for the Amazonian and Cerrado catchments. In combination, these components explained $80 \%$ and $86 \%$ of the variance in the $\mathrm{S}_{b}$ and $\mathrm{S}_{\mathrm{s}}$ values in the Amazonian catchments, and $83 \%$ and $88 \%$ of the variance in the $S_{b}$ and $S_{s}$ values in the Cerrado catchments, respectively. Some parameters, such as TC, TOC, DC and DOC, cluster in the same components in all PCAs with high factor loadings.

22 In all of the PCAs, the first two components account for more than $60 \%$ of the total variance (Fig. 2). For the Amazonian catchments, the first component of the $S_{b}$ PCA (Fig 
1 2a) was mostly correlated with nitrogen and organic carbon, which showed the highest

2 standard deviations. The items that cluster in the second component represent the

3 inorganic carbon and cations ( $\mathrm{Ca}$ and $\mathrm{K})$. The main difference between the $\mathrm{S}_{\mathrm{b}}$ and $\mathrm{S}_{\mathrm{s}}$

4 PCAs (Fig. 2b) is the clustering of $\mathrm{NO}_{3}, \mathrm{TN}$ and $\mathrm{DN}$ in the third component of the $\mathrm{S}_{\mathrm{s}} \mathrm{PCA}$,

5 suggesting that during stormflow events, nitrogen fluxes have a distinct dynamic from that

6 of the other nutrients. For the Cerrado catchments, the first component of the $S_{b}$ PCA

7 (Fig. 2c) groups carbon and $\mathrm{Ca}$, and the second component groups $\mathrm{TN}, \mathrm{DN}$ and $\mathrm{NO}_{3}$.

8 This is the only PCA where the organic and inorganic carbon compounds cluster in the

9 same component. The S PCA (Fig. 2d) shows that the first component groups DOC with

$10 \mathrm{DN}, \mathrm{NO}_{3}$ and $\mathrm{K}$, and the second component shows a high factor loading grouping of TIC,

11 DIC and Ca. The third component of this PCA groups TC, TOC and TN. This is the only

12 PCA where TOC does not group together with DOC, which indicates the importance of

13 particulate organic carbon $(\mathrm{POC})$ in these catchments. We did not directly measure POC

14 in our study, but the differences between TOC and DOC, which could be interpreted as

15 POC (Zhou et al., 2013), were the highest in the Cerrado catchments, representing an

16 average of $19 \%$ of the TOC.

17 Based on the results of the PCAs, we compared TOC, DOC, TIC, DIC, TN and DN (Fig.

18 3), and $\mathrm{NO}_{3}, \mathrm{Ca}$ and $\mathrm{K}$ (Fig. 4). With the exception of higher TOC in the APAS catchment,

$19 \mathrm{~S}_{\mathrm{s}}$ carbon concentrations between the Amazonian catchments did not exhibit significant

20 differences. In the Cerrado catchments, the highest differences were found in $\mathrm{S}_{\mathrm{s}}$, with

21 higher TOC and DOC concentrations in the CPAS catchment compared to those of the

22 CCER (Fig. 3a-b). For DIC, the differences in concentration between the Amazonian

23 catchments in $\mathrm{S}_{b}$ and between the Cerrado catchments in $\mathrm{S}_{\mathrm{s}}$ (Fig. 3c-d) were significant. 
1 Except for $\mathrm{DN}$ in $\mathrm{S}_{\mathrm{b}}$ of the Amazonian catchments, the pasture catchments exhibited

2 higher TN and DN concentrations than those of the native vegetation catchments. The

3 differences in $\mathrm{NO}_{3}$ were significant between the Cerrado catchments, with higher

4 concentrations in the CPAS catchment, whereas there was no significant difference in the

5 Amazonian catchments (Fig. 4a). Differences in Ca concentrations (Fig. 4b) were

6 significant in the catchments of both biomes, but not for the same flow conditions. While

7 the difference in Ca was significant only in $S_{b}$ of the Amazonian catchments, this was only

8 observed in $S_{s}$ of the Cerrado catchments. There were significantly higher $\mathrm{K}$

9 concentrations in both $S_{b}$ and $S_{s}$ for the pasture catchments (Fig. 4c).

4.3. Hydrological and CAN output fluxes

11 The Amazonian catchments exhibited the greater annual average stream discharge with

$12 \quad 23.2 \mathrm{~L} \mathrm{~s}^{-1}$ for the AFOR catchment and $18.3 \mathrm{~L} \mathrm{~s}^{-1}$ for the APAS catchment, whereas the

13 stream discharge for the Cerrado catchments were $11.6 \mathrm{~L} \mathrm{~s}^{-1}$ for the CCER catchment

14 and $13.4 \mathrm{~L} \mathrm{~s}^{-1}$ for the CPAS catchment. The average stream discharge during stormflow

15 events were $94.2 \mathrm{~L} \mathrm{~s}^{-1}$ for the AFOR catchment, 89.5 for the APAS catchment, $11.6 \mathrm{~L} \mathrm{~s}^{-1}$

16 for the CCER catchment and $30.9 \mathrm{~L} \mathrm{~s}^{-1}$ for the CPAS catchment.

17 In the Amazonian catchments, TOC output fluxes were between 35 and $135 \mathrm{~kg} \mathrm{ha}^{-1} \mathrm{yr}^{-1}$, 18 and $\mathrm{K}_{\text {and }} \mathrm{NO}_{3}$ values ranged from 8 to $60 \mathrm{~kg} \mathrm{ha}^{-1} \mathrm{yr}^{-1}$ (Fig. 5). In the Cerrado catchments,

$19 \mathrm{TOC}, \mathrm{Ca}$ and $\mathrm{NO}_{3}$ had total output fluxes between 2 and $12 \mathrm{~kg} \mathrm{ha}^{-1} \mathrm{yr}^{-1}$, and DIC and DN 20 had output fluxes less than $2 \mathrm{~kg} \mathrm{ha}^{-1} \mathrm{yr}^{-1}$. Although the two biomes show different 21 magnitudes of CAN fluxes with higher fluxes in the Amazonian catchments, the $S_{b} C A N$ 22 fluxes were higher than those of the $S_{s}$ in all catchments. Furthermore, the fluxes in the 
1 pasture catchments were generally higher compared to those of the native vegetation

2 catchments.

4 5. Discussion

5 5.1. Stream hydrochemistry

6 Our results showed significantly higher CAN concentrations in the pasture catchments

7 compared to those of the native vegetation catchments, especially for TIC, TN and K.

8 Some other macronutrients ( $\mathrm{Mg}, \mathrm{P}$ and $\mathrm{S})$ and micronutrients $(\mathrm{F}, \mathrm{Cl}, \mathrm{Fe}$ and $\mathrm{Na}$ ) exhibited

9 concentrations of $<1 \mathrm{mg} \mathrm{L}^{-1}$ in all of the studied catchments. Our DOC results for the

10 Amazonian streams are in accordance with other studies of $S_{b}$ of major tributaries of the

11 Amazon River (Moreira-Turcq et al., 2003; Tardy et al., 2005) and in $S_{s}$ of small

12 Amazonian streams (Johnson et al., 2006). Although stream hydrochemistry data are

13 scarce in these regions, studies have reported low stream concentrations for nutrients in

14 a forested catchment in the central Amazon (Zanchi et al., 2015) as well in natural and

15 disturbed catchments in the central and southwestern Cerrado (Silva et al., 2012, 2011).

16 For some nutrients, i.e. $\mathrm{F}$ and $\mathrm{Fe}$, we attributed this to the absence of fertilizer application

17 in the pasture catchments during our study period and the poor soil nutrient conditions in 18 both regions, which is typical of Lixisols (Driessen and Deckers, 2001) and Arenosols

19 (Markewitz et al., 2006) because of their strongly weathered substrate. Additionally, the 20 highly weathered soils fix available nutrients, especially $\mathrm{P}$, in the form of $\mathrm{Fe}$ and $\mathrm{Al}$ 21 sesquioxides (Uehara and Gillman, 1981). Indeed, the soils from all catchments exhibited

22 a high content of $\mathrm{Al}$ and $\mathrm{Fe}$ and, a characteristic often found in Amazon (dos Santos and 23 Alleoni, 2013; Quesada et al., 2011) and Cerrado soils (Buol, 2009). 
1 Soil $\mathrm{pH}$ in the pasture catchments was higher than that in the native vegetation

catchments, which has also been reported in other studies in other regions of the Amazon (Mazzetto et al., 2016) and Cerrado (Carvalho et al., 2007; Hunke et al., 2015b; Neufeldt et al., 2002). This is owing to liming practices in the pasture catchments. Lime $\left(\mathrm{CaCO}_{3}\right)$ is often applied to acidic soils in these regions to increase soil pH (Couto et al., 1997; Jepson et al., 2010; Moreira and Fageria, 2010). Therefore, Ca content was higher in the soils of the pasture catchments than in the soils of the native vegetation catchments. The pasture catchments exhibited significantly higher stream $\mathrm{Ca}$ concentrations, which reported in in other studies in the Amazon (Biggs et al., 2002; Figueiredo et al., 2010) and Cerrado (Markewitz et al., 2011; Silva et al., 2011).

The significantly higher $\mathrm{S}_{\mathrm{s}}$ Ca concentrations exhibited in the CPAS catchment compared to those of the CCER catchment indicates that liming practices are increasing Ca content in the topsoil of the CPAS catchment and facilitating the leaching of this element to the stream during stormflow events. Other studies have already reported that the high rainfall rates in the Cerrado are sufficient to solubilize and leach fertilizers such as $\mathrm{Ca}$ (Hunke et al., 2015a; Villela and Haridasan, 1994). Conversely, between the Amazonian catchments, the Ca concentrations in stream water were significantly higher in the APAS, but only in $\mathrm{S}_{\mathrm{b}}$. Such an enrichment of $\mathrm{Ca}$ in the $\mathrm{S}_{\mathrm{b}}$ has been observed in other studies in Brazil (Da Silva et al., 1998; Gonzatto, 2014), and we attribute this to the slow percolation of the residual lime through the soil profile (Rowe, 1982). Because Lixisols are in an advanced weathering stage (Quesada et al., 2011) and characterized by a low cation exchange capacity (Driessen and Deckers, 2001), the percolating soil water carries the residual $\mathrm{Ca}$, thereby increasing its concentration in the $\mathrm{S}_{\mathrm{b}}$. In contrast, during storm 
1 events, the surface runoff dilutes the Ca concentration in the $S_{b}$, resulting in similar

2 concentrations between the Amazonian catchments. Biggs et al. (2002) found strong correlations between the soil exchangeable cation content and the concentration of

4 stream solutes and suggested that pasture age may help explain the substantial variation

5 in solute concentration responses to deforestation, especially for Ca. DIC presented

6 dynamics similar to $\mathrm{Ca}$; its differences within the Amazonian and Cerrado catchments

7 occur in the same flow types, and they are grouped in the same components in all PCAs.

8 We ascribe this to be a consequence of liming practices. As lime is applied, the $\mathrm{CaCO}_{3}$

9 reacts with water, increasing the soil $\mathrm{pH}$ and producing $\mathrm{HCO}_{3}$, which is one of the main

10 DIC components and has been identified as a main driver of DIC fluxes in small streams

11 in the Amazon (Cak et al., 2015; Johnson et al., 2006).

12 We found $\mathrm{NO}_{3}$ concentrations to be significantly different only between the Cerrado 13 catchments, with higher values in the CPAS catchment. The increase in $\mathrm{NO}_{3}$ 14 concentrations due to deforestation in Amazonian streams are not as clear (Figueiredo 15 et al., 2010; Silva et al., 2007; Williams and Melack, 1997) as they are in the Cerrado 16 (Silva et al., 2011). It has been reported that the high percentage of mineralized $\mathrm{N}$ nitrified

17 in forests is the cause of a high potential for $\mathrm{NO}_{3}$ loss in soil solution and streamwater when these forests are cleared and burned (Neill et al., 2006; Vourlitis and Hentz, 2016), which has occurred in small catchments under recent or ongoing deforestation (Williams 20 and Melack, 1997). The fact that we could not find this same relationship between the

$21 \mathrm{NO}_{3}$ concentrations of the Amazonian catchments is consistent with patterns of $\mathrm{N}$ cycling

22 and $\mathrm{N}$ availability, which shows high soil solution $\mathrm{NO}_{3}$ concentrations in Amazonian

23 forests (Neill et al., 2001). The Amazonian forest behaves rather similar to old and 
1 temperate forests, which present high nitrification rates and $\mathrm{NO}_{3}$ pool losses that occur

2 under normal conditions (Aber et al., 1989; Neill et al., 2001; Stevens et al., 1994). These

3 forests may become net sources of nitrogen, thereby causing $\mathrm{NO}_{3}$ leaching to streams

4 (Aber et al., 1995).

5 5.2. Stream CAN output fluxes

6 Except for DIC in the Cerrado catchments, the CAN fluxes were greater in the pasture

7 catchments (Table 4). The Amazonian catchments exhibited the greatest differences in

8 CAN fluxes. In these catchments, $S_{s}$ showed a greater difference between the APAS and

9 AFOR catchments, with an average APAS:AFOR ratio $37 \%$ higher than that in $\mathrm{S}_{b}$.

10 Conversely, for the Cerrado catchments, the CPAS:CCER CAN ratios were, on average,

$1156 \%$ less in $\mathrm{S}_{\mathrm{s}}$ than in $\mathrm{S}_{\mathrm{b}}$. This is consistent with that fact that nutrients, especially $\mathrm{K}$ and

$12 \mathrm{Ca}$, have been shown to have higher stream fluxes in pastures than in forests in the

13 Amazon (Germer et al., 2009; Williams and Melack, 1997) and Cerrado (Figueiredo et

14 al., 2010; Silva et al., 2011).

15 The total and dissolved carbon stream outputs were higher from the pasture catchments.

16 Strey et al. (2016) found that degraded pasture areas exhibit lower organic carbon (OC)

17 content than that of areas with native vegetation in the Cerrado and Amazon biomes,

18 which is likely connected to larger losses of forest-derived OC after deforestation. In these

19 biomes, the reduced organic carbon due to native vegetation clearing for pasture has

20 been shown to be associated with reduced aggregate stability (Longo et al., 1999), which,

21 in turn, has resulted in degraded pasture soils storing less carbon than soils covered with

22 natural vegetation (Fonte et al., 2014). This facilitates carbon leaching and, consequently,

23 increases the TOC and DOC fluxes. Kindler et al. (2011) affirmed that the quantification 
1 of DOC leaching from soil is crucial for the carbon balance. These authors found that

2 losses of biogenic carbon from grasslands account for ca. $22 \%$ of the net ecosystem exchange, whereas leaching from forest sites hardly affects net ecosystem carbon

4 balances. In the Amazon, the decreased soil carbon storage as a consequence of forest conversion to pastures has been reported to be directly correlated with pasture age

6 (Asner et al., 2004). In the Cerrado, while well-managed pastures may sustain soil carbon

7 content, most pastures in this biome are in advanced stages of degradation (Davidson et

8 al., 2012). In this region, the sandy soils, such as the Arenosols, are commonly found and

9 the decrease of their organic matter content owing to their increasingly use for agricultural practices (Speratti et al., 2017) is likely to increase the leaching of nutrients (Hunke et al., 11 2015a).

12 The results of $\mathrm{C}$ content and $\mathrm{C}: \mathrm{N}$ ratios for the Amazonian catchments are in accordance with studies on primary forests and old pastures in the Amazon (McGrath et al., 2001).

14 For the Cerrado catchments, the $\mathrm{C}: \mathrm{N}$ ratios are also similar to other results for topsoil in

15 areas with cerrado vegetation and pasture in this biome (Figueiredo et al., 2010; Neufeldt et al., 2002). Similar to $\mathrm{C}, \mathrm{N}$ output fluxes were higher in the pasture catchments. In

17 comparison to the Cerrado catchments, the Amazonian catchments exhibited a lower C:N ratio, which is typical for Oxisols in the uppermost horizon (Tardy et al., 2005), and has been identified as an important controlling factor of total ecosystem $\mathrm{N}$ retention. High C:N 20 promotes $\mathrm{N}$ immobilization, reduces net nitrification and consequently contributes to 21 greater $\mathrm{N}$ retention (Templer et al., 2012). This has direct implications for the net $\mathrm{N}$ fluxes 22 in this region, as the atmospheric deposition of $\mathrm{N}\left(3.5-10 \mathrm{~kg} \mathrm{~N} \mathrm{ha}^{-1}\right.$ year ${ }^{-1}$ (Bobbink et 23 al., 2010; Salemi et al., 2015)) is exceeded by $\mathrm{N}$ output via streamflow in the APAS 
1 catchment. This indicates that the pastures in this region might be a sink for $\mathrm{N}$, as has

2 been found in other studies in the Amazon (e.g., Germer et al., 2009 and Salemi et al., 3 2015).

4 Our results show the importance of $S_{s}$ as a significant contributor to $S_{t}$ CAN fluxes in 5 catchments of the Amazon and Cerrado biomes. To illustrate this, we provide the ratios

6 between the short-lived events $\left(S_{s}\right)$ to the $S_{t}$ duration, volume and CAN fluxes in Table 5.

7 The $S_{s}: S_{t}$ duration ratios were only $4.9-5.3 \%$ in the Amazonian catchments and $1.7-2.1 \%$

8 in the Cerrado catchments. Nevertheless, the relatively small durations of the $S_{s}$ events

9 caused an increase of $15.9-26.5 \%$ and $2.8-5.5 \%$ in the $S_{t}$ volume in the Amazonian and

10 Cerrado catchments, respectively. Moreover, in nearly all cases the $\mathrm{S}_{\mathrm{s}}$ contribution to the $11 S_{t}$ CAN output fluxes was greater than its contribution to the $S_{t}$ volume. In the APAS

12 catchment, $50 \%$ of the $S_{t}$ DOC output fluxes were caused by $S_{s}$. In the Cerrado 13 catchments, Ss fluxes accounted for $16-26 \%$ of the TOC total streamflow output fluxes, 14 despite the $S_{s}$ contribution to $S_{t}$ volume of only approximately $2-5 \%$. This shows that $S_{s}$ 15 is especially important as a rapid hydrological pathway for CAN losses in areas on the 16 AAF where deforestation reduces the infiltration capacity rates, which are in turn 17 exceeded by the rainfall intensities, causing greater stormflow contributions 18 (Zimmermann et al., 2006). The substantial contribution exhibited by $S_{s}$ to $S_{t}$ CAN fluxes 19 is mainly owing to their higher CAN concentrations compared to those of $\mathrm{Sb}$. These 20 concentrations may be higher in $\mathrm{S}_{\mathrm{s}}$ because of the rapid subsurface response in streams 21 dominated by pre-event water, where a rapid mobilization of old water occurs (Kirchner, 22 2003), and to surface flow paths that contribute to higher CAN concentrations (Johnson 23 et al., 2006). 
1 DIC also exhibits a rapid response during stormflows in wet tropical catchments under

2 pristine rainforest and agriculture LULC (Bass et al., 2014). In the Amazonian catchments,

3 we found that $S_{s}$ represented slightly more than $30 \%$ of $S_{t}$ DIC fluxes, with similar $S_{s} S_{t}$

4 DIC fluxes between these catchments. In contrast, $S_{s}$ DIC fluxes represented only $6 \%$ of

5 the total output fluxes in the CCER catchment and 10\% in the CPAS catchment.

6 While many recent studies showed insights of high-temporal monitoring schemes in areas

7 with fairly easy access (e.g., close to urban centers accessed via paved roads) in Europe

8 (e.g., Blaen et al., 2016; Cuomo and Guida, 2016) and North America (e.g., Jollymore et

9 al., 2012; Sherson et al., 2015) as a valid and new approach to ensure appropriate

10 management of the natural resources (Skeffington et al., 2015), our study uses this

11 method to assess the impacts of LULC change in catchments located in data-scarce

12 active zones of deforestation of the two largest biomes of South America.

13 Despite the contribution of our study contributes to the understanding of the 14 hydrochemical fluxes on the AFF, the magnitude and duration of these impacts depend on several catchments characteristics (e.g., soils, morphology and geology) that should also be addressed in further studies (Birkinshaw et al., 2010). Long-term measurements (over 10 years) of stormflow events including quantifying changes in groundwater quality are required to analyze trends in water quality. Biggs et al. (2006) found evidence of longterm increases in solute fluxes following the conversion of forest to pasture in the Amazon. Hence, empirical studies that contemplate the comparison of pastures with different ages are fundamental to quantify the effect pasture age in CAN fluxes.

The degree to which the chemical changes of the streamwater in the Amazon and Cerrado biomes are affecting the CAN delivery to the ocean is poorly understood and 
1 difficult to assess (Bouchez et al., 2014). Notwithstanding, the changes in stream

2 hydrochemistry are likely to unfold greater impacts due to several large dams under

3 construction in this region (Pavanato et al., 2016; Tollefson, 2015), which will receive and

4 store the increased loads of CAN and negatively affect their suitability as aquatic habitats.

5 To that end, we recommend studies that take into account the long-term effects of LULC

6 change on stream hydrochemistry in nested scales and their impacts in large watershed

7 systems in this region.

8 6. Conclusions

9 Our research demonstrates how the conversion of natural vegetated landscapes (forest 10 and cerrado) to pasture changes stream hydrochemistry, which can disturb the natural

11 carbon and nutrient balance in the Amazon and Cerrado biomes. Stream carbon and 12 nutrient concentrations were significantly higher in catchments where the native 13 vegetation was replaced by pastures. These higher concentrations underlie further 14 implications for carbon and nutrient fluxes as streamflow increase occurs, which is widely 15 reported in this region as a consequence of the conversion of native vegetation into 16 agricultural lands.

17 We found that most of the carbon and nutrient flux contributions of stormflow to total 18 streamflow is proportionately greater than its respective volumetric contribution to stream discharge. This shows that stormflow is a substantial hydrological pathway for carbon and nutrient losses, including areas with small stormflow contribution, as shown in the Cerrado 21 catchments. This indicates that the unaccounted stream carbon and nutrient fluxes

22 derived from sampling approaches on a daily or weekly basis are substantially great. Our 23 study confirms the need for detailed temporal data on stream hydrochemistry that include 
1 the sampling of short-lived stormflow events to not only to understand natural tropical

2 ecosystems, but also to unveil impacts of anthropogenic changes in these environments.

3 Although the acquisition of high-temporal resolution data in tropical forests is often limited

4 by logistical restraints, we recommend that further studies use novel monitoring

5 techniques such as automatic overland flow sampling and real-time water-quality sensors

6 to improve the understanding of hydrochemical pathways and fluxes in forest ecosystems

7 under anthropogenic changes such as the Amazonian agricultural frontier.

8 Acknowledgments

9 This research was supported by the Bundesministerin für Bildung und Forschung 10 (www.bmbf.de) through a grant to the CarBioCial project (grant number: 01 LL0902A).

11 The authors also acknowledge financial support from the Fundação de Amparo à 12 Pesquisa do Estado de Mato Grosso (www.fapemat.mt.gov.br; grant number: 13 335908/2012), the Brazilian National Council for Scientific and Technological 14 Development (www.cnpq.br; grant number: 481990/2013-5), and the German Academic 15 Exchange Service (DAAD). The authors also acknowledge the collaboration of field site 16 hosts (Paraíso, Gianetta and Rancho do Sol farms); the field assistance of J. Macedo, A.

17 Kirst, N. Bertão and T. Santos; and the technical support provided by A. Eykelbosh, A. 18 Södje, J. Grotheer, P. Voigt and T. Zeppenfeld. The authors also wish to thank all six 19 reviewers for their comments and suggestions.

21 Aber, J.D., Magill, A., Mcnulty, S.G., Boone, R.D., Nadelhoffer, K.J., Downs, M., Hallett, 22 R., 1995. Forest biogeochemistry and primary production altered by nitrogen 
saturation. Water, Air, Soil Pollut. 85, 1665-1670. doi:10.1007/BF00477219

Aber, J.D., Nadelhoffer, K.J., Steudler, P., Melillo, J.M., 1989. Nitrogen Saturation in Northern Forest EcosystemsExcess nitrogen from fossil fuel combustion may stress the biosphere. Bioscience 39, 378-386. doi:10.2307/1311067

Alexander, R.B., Smith, R. a, Schwarz, G.E., 2000. Effect of stream channel size on the delivery of nitrogen to the Gulf of Mexico. Nature 403, 758-761. doi:10.1038/35001562

Andreae, M.O., Acevedo, O.C., Araùjo, A., Artaxo, P., Barbosa, C.G.G., Barbosa, H.M.J., Brito, J., Carbone, S., Chi, X., Cintra, B.B.L., da Silva, N.F., Dias, N.L., Dias-Júnior, C.Q., Ditas, F., Ditz, R., Godoi, A.F.L., Godoi, R.H.M., Heimann, M., Hoffmann, T., Kesselmeier, J., Könemann, T., Krüger, M.L., Lavric, J. V., Manzi, A.O., Lopes, A.P., Martins, D.L., Mikhailov, E.F., Moran-Zuloaga, D., Nelson, B.W., Nölscher, A.C., Santos Nogueira, D., Piedade, M.T.F., Pöhlker, C., Pöschl, U., Quesada, C.A., Rizzo, L. V., Ro, C.-U., Ruckteschler, N., Sá, L.D.A., de Oliveira Sá, M., Sales, C.B., dos Santos, R.M.N., Saturno, J., Schöngart, J., Sörgel, M., de Souza, C.M., de Souza, R.A.F., Su, H., Targhetta, N., Tóta, J., Trebs, I., Trumbore, S., van Eijck, A., Walter, D., Wang, Z., Weber, B., Williams, J., Winderlich, J., Wittmann, F., Wolff, S., Yáñez-Serrano, A.M., 2015. The Amazon Tall Tower Observatory (ATTO): overview of pilot measurements on ecosystem ecology, meteorology, trace gases, and aerosols. Atmos. Chem. Phys. 15, 10723-10776. doi:10.5194/acp-15-10723-2015

Armenteras, D., Rodríguez, N., Retana, J., 2013. Landscape Dynamics in Northwestern 
Amazonia: An Assessment of Pastures, Fire and Illicit Crops as Drivers of Tropical Deforestation. PLoS One 8, e54310. doi:10.1371/journal.pone.0054310

Asner, G.P., Townsend, A.R., Bustamante, M.M.C., Nardoto, G.B., Olander, L.P., 2004. Pasture degradation in the central Amazon: linking changes in carbon and nutrient cycling with remote sensing. Glob. Chang. Biol. 10, 844-862. doi:10.1111/j.15298817.2003.00766.x

Avagyan, A., Runkle, B.R.K., Kutzbach, L., 2014. Application of high-resolution spectral absorbance measurements to determine dissolved organic carbon concentration in remote areas. J. Hydrol. 517, 435-446. doi:10.1016/j.jhydrol.2014.05.060

Barona, E., Ramankutty, N., Hyman, G., Coomes, O.T., 2010. The role of pasture and soybean in deforestation of the Brazilian Amazon. Environ. Res. Lett. 5, 24002. doi:10.1088/1748-9326/5/2/024002

Bass, A.M., Bird, M.I., Liddell, M.J., Nelson, P.N., 2011. Fluvial dynamics of dissolved and particulate organic carbon during periodic discharge events in a steep tropical rainforest catchment. Limnol. Oceanogr. 56, 2282-2292. doi:10.4319/lo.2011.56.6.2282

Bass, A.M., Munksgaard, N.C., Leblanc, M., Tweed, S., Bird, M.I., 2014. Contrasting carbon export dynamics of human impacted and pristine tropical catchments in response to a short-lived discharge event. Hydrol. Process. 28, 1835-1843. doi:10.1002/hyp.9716

Biggs, T.W., Dunne, T., Domingues, T.F., Martinelli, L.A., 2002. Relative influence of natural watershed properties and human disturbance on stream solute 
concentrations in the southwestern Brazilian Amazon basin. Water Resour. Res. 38, 25-1-25-16. doi:10.1029/2001WR000271

Biggs, T.W., Dunne, T., Muraoka, T., 2006. Transport of water, solutes and nutrients from a pasture hillslope, southwestern Brazilian Amazon. Hydrol. Process. 20, 2527-2547. doi:10.1002/hyp.6214

Birkinshaw, S.J., O’Donnell, G.M., Moore, P., Kilsby, C.G., Fowler, H.J., Berry, P.A.M., 2010. Using satellite altimetry data to augment flow estimation techniques on the Mekong River. Hydrol. Process. 24, 3811-3825. doi:10.1002/hyp.7811

Blaen, P.J., Khamis, K., Lloyd, C.E.M., Bradley, C., Hannah, D., Krause, S., 2016. Realtime monitoring of nutrients and dissolved organic matter in rivers: Capturing event dynamics, technological opportunities and future directions. Sci. Total Environ. 569-570, 647-660. doi:10.1016/j.scitotenv.2016.06.116

Bobbink, R., Hicks, K., Galloway, J., Spranger, T., Alkemade, R., Ashmore, M., Bustamante, M., Cinderby, S., Davidson, E., Dentener, F., Emmett, B., Erisman, J.W., Fenn, M., Gilliam, F., Nordin, A., Pardo, L., De Vries, W., 2010. Global assessment of nitrogen deposition effects on terrestrial plant diversity: a synthesis. Ecol. Appl. 20, 30-59. doi:10.1890/08-1140.1

Bouchez, J., Galy, V., Hilton, R.G., Gaillardet, J., Moreira-Turcq, P., Pérez, M.A., France-Lanord, C., Maurice, L., 2014. Source, transport and fluxes of Amazon River particulate organic carbon: Insights from river sediment depth-profiles. Geochim. Cosmochim. Acta 133, 280-298. doi:10.1016/j.gca.2014.02.032 
change in the Brazilian Savanna (Cerrado), 1986-2002: Comparative analysis and implications for land-use policy. Land use policy 25, 579-595. doi:10.1016/j.landusepol.2007.11.008

Brown, A.E., Zhang, L., McMahon, T.A., Western, A.W., Vertessy, R.A., 2005. A review of paired catchment studies for determining changes in water yield resulting from alterations in vegetation. J. Hydrol. 310, 28-61. doi:10.1016/j.jhydrol.2004.12.010

Buol, S.W., 2009. Soils and agriculture in central-west and north Brazil. Sci. Agric. 66, 697-707. doi:10.1590/S0103-90162009000500016

Cak, A.D., Moran, E.F., Figueiredo, R.D.O., Lu, D., Li, G., Hetrick, S., 2015. Urbanization and small household agricultural land use choices in the Brazilian Amazon and the role for the water chemistry of small streams. J. Land Use Sci. 4248, 1-19. doi:10.1080/1747423X.2015.1047909

Canadell, J., Jackson, R.B., Ehleringer, J.B., Mooney, H. a., Sala, O.E., Schulze, E.-D., 1996. Maximum rooting depth of vegetation types at the global scale. Oecologia 108, 583-595. doi:10.1007/BF00329030

Carvalho, J.L.N., Cerri, C.E.P., Cerri, C.C., Feigl, B.J., Píccolo, M.C., Godinho, V.P., Herpin, U., 2007. Changes of chemical properties in an oxisol after clearing of native Cerrado vegetation for agricultural use in Vilhena, Rondonia State, Brazil. Soil Tillage Res. 96, 95-102. doi:10.1016/j.still.2007.04.001

Chaussê, T.C.C., dos Santos Brandão, C., da Silva, L.P., Salamim Fonseca Spanghero, P.E., da Silva, D.M.L., 2016. Evaluation of nutrients and major ions in streams-implications of different timescale procedures. Environ. Monit. Assess. 

188, 38. doi:10.1007/s10661-015-5034-0

Christophersen, N., Clair, T.A., Driscoll, C.T., Jeffries, D.S., Neal, C., Semkin, R.G., 1994. Hydrochemical Studies, in: Moldan, B., Cerny, J. (Eds.), Biogeochemistry of Small Catchments: A Tool for Environmental Research. J. Wiley, Chichester, West Sussex, England, pp. 285-297.

Clark, J.M., Lane, S.N., Chapman, P.J., Adamson, J.K., 2007. Export of dissolved organic carbon from an upland peatland during storm events: Implications for flux estimates. J. Hydrol. 347, 438-447. doi:10.1016/j.jhydrol.2007.09.030

Coe, M.T., Marthews, T.R., Costa, M.H., Galbraith, D.R., Greenglass, N.L., Imbuzeiro, H.M. a, Levine, N.M., Malhi, Y., Moorcroft, P.R., Muza, M.N., Powell, T.L., Saleska, S.R., Solorzano, L. a, Wang, J., 2013. Deforestation and climate feedbacks threaten the ecological integrity of south-southeastern Amazonia. Philos. Trans. R. Soc. Lond. B. Biol. Sci. 368, 20120155. doi:10.1098/rstb.2012.0155

Cohn, A.S., Gil, J., Berger, T., Pellegrina, H., Toledo, C., 2016. Patterns and processes of pasture to crop conversion in Brazil: Evidence from Mato Grosso State. Land use policy 55, 108-120. doi:10.1016/j.landusepol.2016.03.005

Couto, E.G., Stein, a, Klamt, E., 1997. Large area spatial variability of soil chemical properties in central Brazil. Agric. Ecosyst. Environ. 66, 139-152. doi:Doi 10.1016/S0167-8809(97)00076-5

Crossman, J., Futter, M.N., Whitehead, P.G., Stainsby, E., Baulch, H.M., Jin, L., Oni, S.K., Wilby, R.L., Dillon, P.J., 2014. Flow pathways and nutrient transport mechanisms drive hydrochemical sensitivity to climate change across catchments 
with different geology and topography. Hydrol. Earth Syst. Sci. 18, 5125-5148. doi:10.5194/hess-18-5125-2014

Cuo, L., Zhang, Y., Gao, Y., Hao, Z., Cairang, L., 2013. The impacts of climate change and land cover/use transition on the hydrology in the upper Yellow River Basin, China. J. Hydrol. 502, 37-52. doi:10.1016/j.jhydrol.2013.08.003

Cuomo, A., Guida, D., 2016. Using hydro-chemograph analyses to reveal runoff generation processes in a Mediterranean catchment. Hydrol. Process. 30, 44624476. doi:10.1002/hyp.10935

Da Silva, N.M., Van Raij, B., De Carvalho, L.H., Bataglia, O.C., Kondo, J.I., 1998. Efeitos do calcário e do gesso nas características químicas do solo e na cultura do algodão. Bragantia 56, 389-401. doi:10.1590/S0006-87051997000200018

Davidson, E.A., de Araújo, A.C., Artaxo, P., Balch, J.K., Brown, I.F., C. Bustamante, M.M., Coe, M.T., DeFries, R.S., Keller, M., Longo, M., Munger, J.W., Schroeder, W., Soares-Filho, B.S., Souza, C.M., Wofsy, S.C., 2012. The Amazon basin in transition. Nature 481, 321-328. doi:10.1038/nature10717

de Moraes, J.M., Schuler, A.E., Dunne, T., Figueiredo, R. de O., Victoria, R.L., 2006. Water storage and runoff processes in plinthic soils under forest and pasture in eastern Amazonia. Hydrol. Process. 20, 2509-2526. doi:10.1002/hyp.6213

de Paula, J.D., Luizão, F.J., Piedade, M.T.F., 2016. The size distribution of organic carbon in headwater streams in the Amazon basin. Environ. Sci. Pollut. Res. 23, 11461-11470. doi:10.1007/s11356-016-6041-6 
1 Dias, L.C.P., Macedo, M.N., Costa, M.H., Coe, M.T., Neill, C., 2015. Effects of land cover change on evapotranspiration and streamflow of small catchments in the Upper Xingu River Basin, Central Brazil. J. Hydrol. Reg. Stud. 4, 108-122. doi:10.1016/j.ejrh.2015.05.010

DIN ISO 11277:2002-08, 2002. Bodenbeschaffenheit - Bestimmung der Partikelgrößenverteilung in Mineralböden - Verfahren mittels Siebung und Sedimentation. ISO 11277: 1998/Cor.1:2002. Beuth Verlag, Berlin, Germany.

Do Vale, I., Miranda, I.S., Mitja, D., Grimaldi, M., Nelson, B.W., Desjardins, T., Costa, L.G.S., 2015. Tree Regeneration Under Different Land-Use Mosaics in the Brazilian Amazon's “Arc of Deforestation." Environ. Manage. 56, 342-354. doi:10.1007/s00267-015-0500-6

dos Santos, S.N., Alleoni, L.R.F., 2013. Reference values for heavy metals in soils of the Brazilian agricultural frontier in Southwestern Amazônia. Environ. Monit. Assess. 185, 5737-5748. doi:10.1007/s10661-012-2980-7

Driessen, P., Deckers, J., 2001. Lecture notes on the major soils of the world, World Soil Resources Reports. Rome.

Durieux, L., 2003. The impact of deforestation on cloud cover over the Amazon arc of deforestation. Remote Sens. Environ. 86, 132-140. doi:10.1016/S00344257(03)00095-6

Eckhardt, K., 2005. How to construct recursive digital filters for baseflow separation. Hydrol. Process. 19, 507-515. doi:10.1002/hyp.5675 
El-Khoury, a., Seidou, O., Lapen, D.R., Que, Z., Mohammadian, M., Sunohara, M., Bahram, D., 2015. Combined impacts of future climate and land use changes on discharge, nitrogen and phosphorus loads for a Canadian river basin. J. Environ. Manage. 151, 76-86. doi:10.1016/j.jenvman.2014.12.012

Fearnside, P.M., 2001. Soybean cultivation as a threat to the environment in Brazil. Environ. Conserv. doi:10.1017/S0376892901000030

Figueiredo, R.O., Markewitz, D., Davidson, E.A., Schuler, A.E., Dos S. Watrin, O., De Souza Silva, P.P., 2010. Land-use effects on the chemical attributes of low-order streams in the eastern Amazon. J. Geophys. Res. 115, G04004. doi:10.1029/2009JG001200

Figueiredo, C.C. De, Resck, D.V.S., Carneiro, M.A.C., 2010. Labile and stable fractions of soil organic matter under management systems and native cerrado. Rev. Bras. Ciência do Solo 34, 907-916. doi:10.1590/S0100-06832010000300032

Fonte, S.J., Nesper, M., Hegglin, D., Velásquez, J.E., Ramirez, B., Rao, I.M., Bernasconi, S.M., Bünemann, E.K., Frossard, E., Oberson, A., 2014. Pasture degradation impacts soil phosphorus storage via changes to aggregate-associated soil organic matter in highly weathered tropical soils. Soil Biol. Biochem. 68, 150157. doi:10.1016/j.soilbio.2013.09.025

Furley, P.A., 1999. The nature and diversity of neotropical savanna vegetation with particular reference to the Brazilian cerrados. Glob. Ecol. Biogeogr. 8, 223-241. doi:10.1046/j.1466-822X.1999.00142.x

Germer, S., Neill, C., Krusche, A. V., Elsenbeer, H., 2010. Influence of land-use change 
on near-surface hydrological processes: Undisturbed forest to pasture. J. Hydrol. 380, 473-480. doi:10.1016/j.jhydrol.2009.11.022

Germer, S., Neill, C., Vetter, T., Chaves, J., Krusche, A. V., Elsenbeer, H., 2009. Implications of long-term land-use change for the hydrology and solute budgets of small catchments in Amazonia. J. Hydrol. 364, 349-363. doi:10.1016/j.jhydrol.2008.11.013

Gonzatto, R., 2014. Aplicação superficial de calcário: até onde migram e até quando persistem os efeitos no perfil do solo? Federal University of Santa Maria.

Goodland, R., 1971. A physiognomic analysis of the Cerrado vegetation of Central Brasil. J. Ecol. 59, 411-419. doi:10.2307/2258321

Goodland, R., Pollard, R., 1973. The Brazilian Cerrado Vegetation: A Fertility Gradient. J. Ecol. 61, 219-224. doi:10.2307/2258929

Grace, J., José, J.S., Meir, P., Miranda, H.S., Montes, R.A., 2006. Productivity and carbon fluxes of tropical savannas. J. Biogeogr. 33, 387-400. doi:10.1111/j.13652699.2005.01448.x

Guzha, A.C., Nobrega, R.L.B., Kovacs, K., Rebola-Lichtenberg, J., Amorim, R.S.S., Gerold, G., 2015. Characterizing rainfall-runoff signatures from micro-catchments with contrasting land cover characteristics in southern Amazonia. Hydrol. Process. 29, 508-521. doi:10.1002/hyp.10161

Hope, D., Palmer, S.M., Billett, M.F., Dawson, J.J.C., 2004. Variations in dissolved CO2 and $\mathrm{CH} 4$ in a first-order stream and catchment: an investigation of soil-stream 
linkages. Hydrol. Process. 18, 3255-3275. doi:10.1002/hyp.5657

Hughes, F.M.R., Colston, A., Mountford, J.O., 2005. Restoring riparian ecosystems: The challenge of accommodating variability and designing restoration trajectories. Ecol. Soc. 10, 12.

Hunke, P., Mueller, E.N., Schröder, B., Zeilhofer, P., 2015a. The Brazilian Cerrado: assessment of water and soil degradation in catchments under intensive agricultural use. Ecohydrology 8, 1154-1180. doi:10.1002/eco.1573

Hunke, P., Roller, R., Zeilhofer, P., Schröder, B., Mueller, E.N., Nora, E., 2015b. Soil changes under different land-uses in the Cerrado of Mato Grosso, Brazil. Geoderma Reg. 4, 31-43. doi:10.1016/j.geodrs.2014.12.001

Jepson, W., Brannstrom, C., Filippi, A., 2010. Access Regimes and Regional Land Change in the Brazilian Cerrado, 1972-2002. Ann. Assoc. Am. Geogr. 100, 87111. doi:10.1080/00045600903378960

Johnson, M.S., Lehmann, J., Couto, E.G., Filho, J.P.N., Riha, S.J., 2006. DOC and DIC in Flowpaths of Amazonian Headwater Catchments with Hydrologically Contrasting Soils. Biogeochemistry 81, 45-57. doi:10.1007/s10533-006-9029-3

Jollymore, A., Johnson, M.S., Hawthorne, I., 2012. Submersible UV-Vis spectroscopy for quantifying streamwater organic carbon dynamics: implementation and challenges before and after forest harvest in a headwater stream. Sensors (Basel). 12, 3798-813. doi:10.3390/s120403798

Jordan, T.E., Correll, D.L., Weller, D.E., 1997. Relating nutrient discharges from 
watersheds to land use and streamflow variability. Water Resour. Res. 33, 25792590. doi:10.1029/97WR02005

Kaiser, H.F., 1974. An index of factorial simplicity. Psychometrika 39, 31-36. doi:10.1007/BF02291575

Kindler, R., Siemens, J., Kaiser, K., Walmsley, D.C., Bernhofer, C., Buchmann, N., Cellier, P., Eugster, W., Gleixner, G., Grũnwald, T., Heim, A., Ibrom, A., Jones, S.K., Jones, M., Klumpp, K., Kutsch, W., Larsen, K.S., Lehuger, S., Loubet, B., Mckenzie, R., Moors, E., Osborne, B., Pilegaard, K., Rebmann, C., Saunders, M., Schmidt, M.W.I., Schrumpf, M., Seyfferth, J., Skiba, U., Soussana, J.-F., Sutton, M.A., Tefs, C., Vowinckel, B., Zeeman, M.J., Kaupenjohann, M., 2011. Dissolved carbon leaching from soil is a crucial component of the net ecosystem carbon balance. Glob. Chang. Biol. 17, 1167-1185. doi:10.1111/j.1365-2486.2010.02282.x

Kindsvater, C.E., Carter, R.W.C., 1957. Discharge Characteristics of Rectangular Thin Plate Weirs. JProceedings Am. Soc. Civ. Eng. J. Hydraul. Div. 83, 1453/1-1453/36.

King, J.R., Jackson, D. a, 1999. Variable selection in large environmental data sets using principal components analysis. Environmetrics 10, 67-77. doi:10.1002/(SICI)1099-095X(199901/02)10:1<67::AID-ENV336>3.0.CO;2-0

Kirchner, J.W., 2003. A double paradox in catchment hydrology and geochemistry. Hydrol. Process. 17, 871-874. doi:10.1002/hyp.5108

Kirchner, J.W., Neal, C., 2013. Universal fractal scaling in stream chemistry and its implications for solute transport and water quality trend detection. Proc. Natl. Acad. Sci. 110, 12213-12218. doi:10.1073/pnas.1304328110 
Klink, C.A., Machado, R.B., 2005. Conservation of the Brazilian Cerrado. Conserv. Biol. 19, 707-713. doi:10.1111/j.1523-1739.2005.00702.x

Lahsen, M., Nobre, C.A., 2007. Challenges of connecting international science and local level sustainability efforts: the case of the Large-Scale Biosphere-Atmosphere Experiment in Amazonia. Environ. Sci. Policy 10, 62-74. doi:10.1016/j.envsci.2006.10.005

Lambin, E.F., Gibbs, H.K., Ferreira, L., Grau, R., Mayaux, P., Meyfroidt, P., Morton, D.C., Rudel, T.K., Gasparri, I., Munger, J., 2013. Estimating the world's potentially available cropland using a bottom-up approach. Glob. Environ. Chang. 23, 892901. doi:10.1016/j.gloenvcha.2013.05.005

Lamparter, G., Nobrega, R.L.B., Kovacs, K., Amorim, R.S., Gerold, G., 2018. Modelling hydrological impacts of agricultural expansion in two macro-catchments in Southern Amazonia, Brazil. Reg. Environ. Chang. 18, 91-103. doi:10.1007/s10113-016$1015-2$

Lim, K.J., Engel, B.A., Tang, Z., Choi, J., Kim, K.-S., Muthukrishnan, S., Tripathy, D., 2005. Automated Web GIS based hydrograph analysis tool, WHAT. J. Am. Water Resour. Assoc. 41, 1407-1416. doi:10.1111/j.1752-1688.2005.tb03808.x

Lim, K.J., Park, Y.S., Kim, J., Shin, Y.-C., Kim, N.W., Kim, S.J., Jeon, J.-H., Engel, B.A., 2010. Development of genetic algorithm-based optimization module in WHAT system for hydrograph analysis and model application. Comput. Geosci. 36, 936944. doi:10.1016/j.cageo.2010.01.004 
Agregados No Solo Decorrentes Da Introdução De Pastagens Em Áreas De Cerrado E Floresta Amazônica Introduction of Pasture Areas in " Cerrado " and Amazon Forest. Rev. Bras. Eng. Agrícola e Ambient. 3, 276-280. doi:10.1590/1807-1929/agriambi.v3n3p276-280

Luke, S.H., Barclay, H., Bidin, K., Chey, V.K., Ewers, R.M., Foster, W.A., Nainar, A., Pfeifer, M., Reynolds, G., Turner, E.C., Walsh, R.P.D., Aldridge, D.C., 2017. The effects of catchment and riparian forest quality on stream environmental conditions across a tropical rainforest and oil palm landscape in Malaysian Borneo. Ecohydrology 10, e1827. doi:10.1002/eco.1827

Marchman, S.C., Miwa, M., Summer, W.B., Terrell, S., Jones, D.G., Scarbrough, S.L., Jackson, C.R., 2015. Clearcutting and pine planting effects on nutrient concentrations and export in two mixed use headwater streams: Upper Coastal Plain, Southeastern USA. Hydrol. Process. 29, 13-28. doi:10.1002/hyp.10121

Markewitz, D., Lamon, E.C., Bustamante, M.C., Chaves, J., Figueiredo, R.O., Johnson, M.S., Krusche, A., Neill, C., Silva, J.S.O., 2011. Discharge-calcium concentration relationships in streams of the Amazon and Cerrado of Brazil: soil or land use controlled. Biogeochemistry 105, 19-35. doi:10.1007/s10533-011-9574-2

Markewitz, D., Resende, J.C.F., Parron, L., Bustamante, M., Klink, C.A., Figueiredo, R. de O., Davidson, E.A., 2006. Dissolved rainfall inputs and streamwater outputs in an undisturbed watershed on highly weathered soils in the Brazilian cerrado. Hydrol. Process. 20, 2615-2639. doi:10.1002/hyp.6219

Mazzetto, A.M., Feigl, B.J., Cerri, C.E.P., Cerri, C.C., 2016. Comparing how land use 
change impacts soil microbial catabolic respiration in Southwestern Amazon. Brazilian J. Microbiol. 47, 63-72. doi:10.1016/j.bjm.2015.11.025

McGrath, D.A., Smith, C.K., Gholz, H.L., Oliveira, F.D.A., 2001. Effects of land-use change on soil nutrient dynamics in Amaz??nia. Ecosystems 4, 625-645. doi:10.1007/s10021-001-0033-0

Moreira-Turcq, P., Seyler, P., Guyot, J.L., Etcheber, H., 2003. Exportation of organic carbon from the Amazon River and its main tributaries. Hydrol. Process. 17, 13291344. doi:10.1002/hyp.1287

Moreira, A., Fageria, N.K., 2010. Liming influence on soil chemical properties, nutritional status and yield of alfalfa grown in acid soil. Rev. Bras. Ciência do Solo 34, 12311239. doi:10.1590/S0100-06832010000400022

Muñoz-Villers, L.E., McDonnell, J.J., 2013. Land use change effects on runoff generation in a humid tropical montane cloud forest region. Hydrol. Earth Syst. Sci. 17, 3543-3560. doi:10.5194/hess-17-3543-2013

Neary, D.G., 2016. Long-term forest paired catchment studies: What do they tell us that landscape-level monitoring does not? Forests 7, 1-15. doi:10.3390/f7080164

Neill, C., Chaves, J.E., Biggs, T., Deegan, L.A., Elsenbeer, H., Figueiredo, R.O., Germer, S., Johnson, M.S., Lehmann, J., Markewitz, D., Piccolo, M.C., 2011. Runoff sources and land cover change in the Amazon: an end-member mixing analysis from small watersheds. Biogeochemistry 105, 7-18. doi:10.1007/s10533$011-9597-8$ 
Neill, C., Coe, M.T., Riskin, S.H., Krusche, A. V, Elsenbeer, H., Macedo, M.N., McHorney, R., Lefebvre, P., Davidson, E.A., Scheffler, R., Figueira, A.M. e. S., Porder, S., Deegan, L.A., 2013. Watershed responses to Amazon soya bean cropland expansion and intensification. Philos. Trans. R. Soc. B Biol. Sci. 368, 20120425-20120425. doi:10.1098/rstb.2012.0425

Neill, C., Deegan, L.A., Thomas, S.M., Cerri, C.C., 2001. Deforestation for pasture alters nitrogen and phosphorus in small Amazonian streams. Ecol. Appl. 11, 18171828. doi:10.1890/1051-0761(2001)011[1817:DFPANA]2.0.CO;2

Neill, C., Germer, S., Neto, G., Krusche, A., Chaves, J., Neill, C., Germer, S., Neto, S.G., Krusche, A., Elsenbeer, H., 2008. Land management impacts on runoff sources in small Amazon watersheds. Hydrol. Process. 22, 1766-1775. doi:10.1002/hyp.6803

Neill, C., Jankowski, K., Brando, P.M., Coe, M.T., Deegan, L.A., Macedo, M.N., Riskin, S.H., Porder, S., Elsenbeer, H., Krusche, A. V., 2017. Surprisingly Modest Water Quality Impacts From Expansion and Intensification of Large-Sscale Commercial Agriculture in the Brazilian Amazon-Cerrado Region. Trop. Conserv. Sci. 10, 194008291772066. doi:10.1177/1940082917720669

Neill, C., Piccolo, M.C., Cerri, C.C., Steudler, P.A., Melillo, J.M., 2006. Soil solution nitrogen losses during clearing of lowland Amazon forest for pasture. Plant Soil 281, 233-245. doi:10.1007/s11104-005-4435-1

Neufeldt, H., Resck, D.V.S., Ayarza, M.A., 2002. Texture and land-use effects on soil organic matter in Cerrado Oxisols, Central Brazil. Geoderma 107, 151-164. 
doi:10.1016/S0016-7061(01)00145-8

Nóbrega, R.L.B., Guzha, A.C., Torres, G.N., Kovacs, K., Lamparter, G., Amorim, R.S.S., Couto, E., Gerold, G., 2017. Effects of conversion of native cerrado vegetation to pasture on soil hydro-physical properties, evapotranspiration and streamflow on the Amazonian agricultural frontier. PLoS One 12, e0179414. doi:10.1371/journal.pone.0179414

Ogden, F.L., Crouch, T.D., Stallard, R.F., Hall, J.S., 2013. Effect of land cover and use on dry season river runoff, runoff efficiency, and peak storm runoff in the seasonal tropics of Central Panama. Water Resour. Res. 49, 8443-8462. doi:10.1002/2013WR013956

Oliveira, P.T.S., Wendland, E., Nearing, M. a., Scott, R.L., Rosolem, R., da Rocha, H.R., 2015. The water balance components of undisturbed tropical woodlands in the Brazilian cerrado. Hydrol. Earth Syst. Sci. 19, 2899-2910. doi:10.5194/hess-192899-2015

Oni, S.K., Futter, M.N., Molot, L.A., Dillon, P.J., 2014. Adjacent catchments with similar patterns of land use and climate have markedly different dissolved organic carbon concentration and runoff dynamics. Hydrol. Process. 28, 1436-1449. doi:10.1002/hyp.9681

Ouyang, Y., 2005. Evaluation of river water quality monitoring stations by principal component analysis. Water Res. 39, 2621-2635. doi:10.1016/j.watres.2005.04.024

Öztürk, M., Copty, N.K., Saysel, A.K., 2013. Modeling the impact of land use change on the hydrology of a rural watershed. J. Hydrol. 497, 97-109. 
doi:10.1016/j.jhydrol.2013.05.022

Pavanato, H., Melo-Santos, G., Lima, D., Portocarrero-Aya, M., Paschoalini, M., Mosquera, F., Trujillo, F., Meneses, R., Marmontel, M., Maretti, C., 2016. Risks of dam construction for South American river dolphins: a case study of the Tapajós River. Endanger. Species Res. 31, 47-60. doi:10.3354/esr00751

Penaluna, B.E., Olson, D.H., Flitcroft, R.L., Weber, M.A., Bellmore, J.R., Wondzell, S.M., Dunham, J.B., Johnson, S.L., Reeves, G.H., 2017. Aquatic biodiversity in forests: a weak link in ecosystem services resilience. Biodivers. Conserv. 26, 3125-3155. doi:10.1007/s10531-016-1148-0

Pinheiro, T.F., Escada, M.I.S., Valeriano, D.M., Hostert, P., Gollnow, F., Müller, H., 2016. Forest Degradation Associated with Logging Frontier Expansion in the Amazon: The BR-163 Region in Southwestern Pará, Brazil. Earth Interact. 20, 1 26. doi:10.1175/EI-D-15-0016.1

Potter, C., Klooster, S., Genovese, V., 2012. Net primary production of terrestrial ecosystems from 2000 to 2009. Clim. Change 115, 365-378. doi:10.1007/s10584$012-0460-2$

Quesada, C.A., Lloyd, J., Anderson, L.O., Fyllas, N.M., Schwarz, M., Czimczik, C.I., 2011. Soils of Amazonia with particular reference to the RAINFOR sites. Biogeosciences 8, 1415-1440. doi:10.5194/bg-8-1415-2011

R Core Team, 2017. R: A language and environment for statistical computing.

Ratter, J., Ribeiro, J.F., Bridgewater, S., 1997. The Brazilian Cerrado Vegetation and 
Threats to its Biodiversity. Ann. Bot. 80, 223-230. doi:10.1006/anbo.1997.0469

Recha, J.W., Lehmann, J., Walter, M.T., Pell, A., Verchot, L., Johnson, M., 2013. Stream water nutrient and organic carbon exports from tropical headwater catchments at a soil degradation gradient. Nutr. Cycl. Agroecosystems. doi:10.1007/s10705-013-9554-0

Recha, J.W., Lehmann, J., Walter, M.T., Pell, A., Verchot, L., Johnson, M., 2012. Stream Discharge in Tropical Headwater Catchments as a Result of Forest Clearing and Soil Degradation. Earth Interact. 16, 1-18. doi:10.1175/2012EI000439.1

Richey, J.E., Ballester, M.V., Davidson, E.A., Johnson, M.S., Krusche, A. V., 2011. Land-Water interactions in the amazon. Biogeochemistry 105, 1-5. doi:10.1007/s10533-011-9622-y

Richey, J.E., Wilhelm, S.R., Mcclain, M.E., Victoria, R.L., Melack, J.M., Araujo Lima, C., 1997. Organic matter and nutrient dynamics in river corridors of the Amazon Basin and their response to anthropogenic change. Cienc. e Cult. (Sao Paulo). doi:10.1029/20086M000728

Riskin, S.H., Neill, C., Jankowski, K., Krusche, A. V., McHorney, R., Elsenbeer, H., Macedo, M.N., Nunes, D., Porder, S., 2017. Solute and sediment export from Amazon forest and soybean headwater streams: Ecol. Appl. 27, 193-207. doi:10.1002/eap.1428

Riskin, S.H., Porder, S., Neill, C., Figueira, A.M.E.S., Tubbesing, C., Mahowald, N., 2013. The fate of phosphorus fertilizer in Amazon soya bean fields. Philos. Trans. 
Roa-García, M.C., Brown, S., Schreier, H., Lavkulich, L.M., 2011. The role of land use and soils in regulating water flow in small headwater catchments of the Andes. Water Resour. Res. 47, W05510. doi:10.1029/2010WR009582

Rodriguez, D.A., Tomasella, J., Linhares, C., 2010. Is the forest conversion to pasture affecting the hydrological response of Amazonian catchments? Signals in the JiParaná Basin. Hydrol. Process. 24, 1254-1269. doi:10.1002/hyp.7586

Rowe, B.A., 1982. Effects of limestone on pasture yields and the ph of two krasnozems in north-western tasmania. Aust. J. Exp. Agric. 22, 100-105. doi:10.1071/EA9820100

Rufin, P., Müller, H., Pflugmacher, D., Hostert, P., 2015. Land use intensity trajectories on Amazonian pastures derived from Landsat time series. Int. J. Appl. Earth Obs. Geoinf. 41, 1-10. doi:10.1016/j.jag.2015.04.010

Salemi, L.F., Groppo, J.D., Trevisan, R., de Barros Ferraz, S.F., de Moraes, J.M., Martinelli, L.A., 2015. Nitrogen dynamics in hydrological flow paths of a small tropical pasture catchment. Catena 127, 250-257. doi:10.1016/j.catena.2015.01.009

Salemi, L.F., Groppo, J.D., Trevisan, R., de Moraes, J.M., de Barros Ferraz, S.F., Villani, J.P., Duarte-Neto, P.J., Martinelli, L.A., 2013. Land-use change in the Atlantic rainforest region: Consequences for the hydrology of small catchments. J. Hydrol. 499, 100-109. doi:10.1016/j.jhydrol.2013.06.049 
1 Satinsky, B.M., Zielinski, B.L., Doherty, M., Smith, C.B., Sharma, S., Paul, J.H., Crump, B.C., Moran, M., 2014. The Amazon continuum dataset: quantitative metagenomic and metatranscriptomic inventories of the Amazon River plume, June 2010. Microbiome 2, 17. doi:10.1186/2049-2618-2-17

Schierhorn, F., Gittelson, A.K., Müller, D., 2016. How the Collapse of the Beef Sector in Post-Soviet Russia Displaced Competition for Ecosystem Services to the Brazilian Amazon, in: Land Use Competition. Springer International Publishing, Cham, pp. 165-182. doi:10.1007/978-3-319-33628-2_10

Schiesari, L., Waichman, a., Brock, T., Adams, C., Grillitsch, B., 2013. Pesticide use and biodiversity conservation in the Amazonian agricultural frontier. Philos. Trans. R. Soc. Lond. B. Biol. Sci. 368, 20120378. doi:10.1098/rstb.2012.0378

Shen, J., 1981. Discharge Characteristics of Triangular-notch Thin-plate Weirs, Geological Survey water-supply paper. Washington, USA.

Sherson, L.R., Van Horn, D.J., Gomez-Velez, J.D., Crossey, L.J., Dahm, C.N., 2015. Nutrient dynamics in an alpine headwater stream: use of continuous water quality sensors to examine responses to wildfire and precipitation events. Hydrol. Process. 3207, n/a-n/a. doi:10.1002/hyp.10426

Silva, D.M.L., Camargo, P.B., Mcdowell, W.H., Vieira, I., Salomão, M.S.M.B., Martinelli, L.A., 2012. Influence of land use changes on water chemistry in streams in the State of São Paulo, southeast Brazil. An. Acad. Bras. Cienc. 84, 919-930. doi:10.1590/S0001-37652012000400007

Silva, J.S.O., da Bustamante, M.M.C., Markewitz, D., Krusche, A.V., Ferreira, L.G., da 
Cunha Bustamante, M.M., Markewitz, D., Krusche, A.V., Ferreira, L.G., 2011. Effects of land cover on chemical characteristics of streams in the Cerrado region of Brazil. Biogeochemistry 105, 75-88. doi:10.1007/s10533-010-9557-8

Silva, M.E., Pereira, G., Rocha, R., 2013. Increasing deforestation at the Arc of Deforestation in Brazil, in: Geophysical Research Abstracts. Vienna, p. EGU2013$12011-1$.

Silva, D.M.L. da, Ometto, J.P.H.B., Lobo, G. de A., Lima, W.D.P., Scaranello, M.A., Mazzi, E., Rocha, H.R. da, 2007. Can land use changes alter carbon, nitrogen and major ion transport in subtropical brazilian streams? Sci. Agric. 64, 317-324. doi:10.1590/S0103-90162007000400002

Skeffington, R.A., Halliday, S.J., Wade, A.J., Bowes, M.J., Loewenthal, M., 2015. Using high-frequency water quality data to assess sampling strategies for the EU Water Framework Directive. Hydrol. Earth Syst. Sci. 19, 2491-2504. doi:10.5194/hess-19$2491-2015$

Spera, S.A., Galford, G.L., Coe, M.T., Macedo, M.N., Mustard, J.F., 2016. Land-use change affects water recycling in Brazil's last agricultural frontier. Glob. Chang. Biol. 22, 3405-3413. doi:10.1111/gcb.13298

Speratti, A., Johnson, M., Martins Sousa, H., Nunes Torres, G., Guimarães Couto, E., 2017. Impact of Different Agricultural Waste Biochars on Maize Biomass and Soil Water Content in a Brazilian Cerrado Arenosol. Agronomy 7, 49. doi:10.3390/agronomy7030049

Stevens, P.A., Norris, D.A., Sparks, T.H., Hodgson, A.L., 1994. The impacts of 
atmospheric $\mathrm{n}$ inputs on throughfall, soil and stream water interactions for different aged forest and moorland catchments in Wales. Water, Air, Soil Pollut. 73, 297317. doi:10.1007/BF00477994

Strassburg, B.B.N., Brooks, T., Feltran-Barbieri, R., Iribarrem, A., Crouzeilles, R., Loyola, R., Latawiec, A.E., Oliveira Filho, F.J.B., Scaramuzza, C.A. de M., Scarano, F.R., Soares-Filho, B., Balmford, A., 2017. Moment of truth for the Cerrado hotspot. Nat. Ecol. Evol. 1, 99. doi:10.1038/s41559-017-0099

Strey, S., Boy, J., Strey, R., Weber, O., Guggenberger, G., 2016. Response of soil organic carbon to land-use change in central Brazil: a large-scale comparison of Ferralsols and Acrisols. Plant Soil 408, 327-342. doi:10.1007/s11104-016-2901-6

Strohmeier, S., Knorr, K.H., Reichert, M., Frei, S., Fleckenstein, J.H., Peiffer, S., Matzner, E., 2013. Concentrations and fluxes of dissolved organic carbon in runoff from a forested catchment: Insights from high frequency measurements. Biogeosciences 10, 905-916. doi:10.5194/bg-10-905-2013

Sun, J., Tang, C., Wu, P., Strosnider, W.H.J., Han, Z., 2013. Hydrogeochemical characteristics of streams with and without acid mine drainage impacts: A paired catchment study in karst geology, SW China. J. Hydrol. 504, 115-124. doi:10.1016/j.jhydrol.2013.09.029

Tang, J.-L., Zhang, B., Gao, C., Zepp, H., 2008. Hydrological pathway and source area of nutrient losses identified by a multi-scale monitoring in an agricultural catchment. CATENA 72, 374-385. doi:10.1016/j.catena.2007.07.004

Tardy, Y., Bustillo, V., Roquin, C., Mortatti, J., Victoria, R., 2005. The Amazon. Bio- 
geochemistry applied to river basin management: Part I. Hydro-climatology, hydrograph separation, mass transfer balances, stable isotopes, and modelling. Appl. Geochemistry 20, 1746-1829. doi:10.1016/j.apgeochem.2005.06.001

Templer, P.H., Mack, M.C., III, F.S.C., Christenson, L.M., Compton, J.E., Crook, H.D., Currie, W.S., Curtis, C.J., Dail, D.B., D’Antonio, C.M., Emmett, B.A., Epstein, H.E., Goodale, C.L., Gundersen, P., Hobbie, S.E., Holland, K., Hooper, D.U., Hungate, B.A., Lamontagne, S., Nadelhoffer, K.J., Osenberg, C.W., Perakis, S.S., Schleppi, P., Schimel, J., Schmidt, I.K., Sommerkorn, M., Spoelstra, J., Tietema, A., Wessel, W.W., Zak, D.R., 2012. Sinks for nitrogen inputs in terrestrial ecosystems: a metaanalysis of $15 \mathrm{~N}$ tracer field studies. Ecology 93, 1816-1829. doi:10.1890/111146.1

Tollefson, J., 2015. Stopping deforestation: Battle for the Amazon. Nature 520, 20-23. doi:10.1038/520020a

Troch, P.A., Lahmers, T., Meira, A., Mukherjee, R., Pedersen, J.W., Roy, T., ValdésPineda, R., 2015. Catchment coevolution: A useful framework for improving predictions of hydrological change? Water Resour. Res. 51, 4903-4922. doi:10.1002/2015WR017032

Uehara, G., Gillman, G., 1981. The Mineralogy, Chemistry, and Physics of Tropical Soils with Variable-Charge Clays. West-View Press, Buolder, Colorado.

Valle, R.F., Varandas, S.G.P., Sanches Fernandes, L.F., Pacheco, F.A.L., 2014. Groundwater quality in rural watersheds with environmental land use conflicts. Sci. Total Environ. 493, 812-827. doi:10.1016/j.scitotenv.2014.06.068 
Valle Junior, R.F., Varandas, S.G.P., Pacheco, F.A.L., Pereira, V.R., Santos, C.F., Cortes, R.M.V., Sanches Fernandes, L.F., 2015. Impacts of land use conflicts on riverine ecosystems. Land use policy $43,48-62$. doi:10.1016/j.landusepol.2014.10.015

Villela, D.M., Haridasan, M., 1994. Response of the ground layer community of a cerrado vegetation in central Brazil to liming and irrigation. Plant Soil 163, 25-31. doi:10.1007/BF00033937

Vogt, E., Braban, C.F., Dragosits, U., Durand, P., Sutton, M.A., Theobald, M.R., Rees, R.M., McDonald, C., Murray, S., Billett, M.F., 2015. Catchment land use effects on fluxes and concentrations of organic and inorganic nitrogen in streams. Agric. Ecosyst. Environ. 199, 320-332. doi:10.1016/j.agee.2014.10.010

Vourlitis, G.L., Hentz, C.S., 2016. Impacts of chronic N input on the carbon and nitrogen storage of a postfire Mediterranean-type shrubland. J. Geophys. Res. G Biogeosciences 121, 385-398. doi:10.1002/2015JG003220

Williams, M.R., Melack, J.M., 1997. Solute export from forested and partially deforested catchments in the central Amazon. Biogeochemistry 38, 67-102. doi:10.1023/A:1005774431820

Wohl, E., Barros, A., Brunsell, N., Chappell, N.A., Coe, M., Giambelluca, T., Goldsmith, S., Harmon, R., Hendrickx, J.M.H., Juvik, J., McDonnell, J., Ogden, F., 2012. The hydrology of the humid tropics. Nat. Clim. Chang. 2, 655-662. doi:10.1038/nclimate1556

Yan, J., Li, K., Wang, W., Zhang, D., Zhou, G., 2015. Changes in dissolved organic 
carbon and total dissolved nitrogen fluxes across subtropical forest ecosystems at different successional stages. Water Resour. Res. 51, 3681-3694. doi:10.1002/2015WR016912

Zanchi, F.B., Waterloo, M.J., Tapia, A.P., Alvarado Barrientos, M.S., Bolson, M. a., Luizão, F.J., Manzi, A.O., Dolman, A.J., 2015. Water balance, nutrient and carbon export from a heath forest catchment in central Amazonia, Brazil. Hydrol. Process. 3648, n/a-n/a. doi:10.1002/hyp.10458

Zeinalzadeh, K., Rezaei, E., 2017. Determining spatial and temporal changes of surface water quality using principal component analysis. J. Hydrol. Reg. Stud. 13, 1-10. doi:10.1016/j.ejrh.2017.07.002

Zhang, Y., Guo, F., Meng, W., Wang, X.-Q., 2009. Water quality assessment and source identification of Daliao river basin using multivariate statistical methods. Environ. Monit. Assess. 152, 105-121. doi:10.1007/s10661-008-0300-z

Zhao, M., Zeng, C., Liu, Z., Wang, S., 2010. Effect of different land use/land cover on karst hydrogeochemistry: A paired catchment study of Chenqi and Dengzhanhe, Puding, Guizhou, SW China. J. Hydrol. 388, 121-130. doi:10.1016/j.jhydrol.2010.04.034

Zhou, W., Zhang, Y., Schaefer, D.A., Sha, L., Deng, Y., 2013. The Role of Stream Water Carbon Dynamics and Export in the Carbon Balance of a Tropical Seasonal Rainforest, Southwest China 8. doi:10.1371/journal.pone.0056646

Zimmermann, B., Elsenbeer, H., De Moraes, J.M., 2006. The influence of land-use changes on soil hydraulic properties: Implications for runoff generation. For. Ecol. 
1

Manage. 222, 29-38. doi:10.1016/j.foreco.2005.10.070

2

3 
3 Figure 1. Study areas in the Amazon and Cerrado biomes.

4 Figure 2. Biplots of the PCAs after varimax rotation for the first (C1) and second (C2) components

5 of the: a) Amazon catchments base streamflow ( $\left.S_{b}\right)$; b) Amazon catchments storm streamflow

$6 \quad\left(S_{s}\right)$; c) Cerrado catchments base streamflow $\left(S_{b}\right)$; and d) Cerrado storm streamflow $\left(S_{s}\right)$.

7 Figure 3. Boxplot and violin plots of non-flow weighted carbon and nitrogen concentrations in base

8 streamflow and storm streamflow. The violin plots indicate the density of the sample distribution

9 across the y-values. The y-axis was limited to exclude some outliers (only graphically) for better

10 visualization of the results. NS stands for not significant and ${ }^{*},{ }^{* *}$ and ${ }^{* * *}$ indicate statistical

11 significance at the $.05, .01$ and .001 probability levels, respectively. The significance of the results was based on the MW and Mood tests. When the test type is not indicated, the result is valid for both tests.

14 Figure 4. Boxplot and violin plots of $\mathrm{NO}_{3}, \mathrm{Ca}$ and $\mathrm{K}$ non-flow weighted concentrations in base 15 streamflow and storm streamflow. The violin plots indicate the density of the sample distribution 16 across the y-values. The y-axis was limited to exclude some outliers (only graphically) for better 17 visualization of the results. NS stands for not significant and ${ }^{*},{ }^{* *}$ and ${ }^{* * *}$ indicate the statistical 18 significance at the $.05, .01$ and .001 probability levels, respectively. The significance results were 19 based on the MW and Mood tests. When the test type is not indicated, the result is valid for both 20 tests.

21 Figure 5. Annual carbon and nutrient output fluxes of base streamflow $\left(\mathrm{S}_{\mathrm{b}}\right)$ and storm streamflow $22\left(S_{s}\right)$. 


\begin{tabular}{|c|c|c|c|c|}
\hline & \multicolumn{2}{|c|}{ Amazonian catchments } & \multicolumn{2}{|c|}{ Cerrado catchments } \\
\hline & AFOR & APAS & CCER & CPAS \\
\hline Biome & \multicolumn{2}{|c|}{ Amazon } & \multicolumn{2}{|c|}{ Cerrado } \\
\hline Area (ha) & 93.4 & 23.1 & 77.8 & 58.4 \\
\hline $\begin{array}{c}\text { Mean precipitation } \\
\qquad\left(\mathrm{mm} \mathrm{yr}^{-1}\right)\end{array}$ & \multicolumn{2}{|c|}{1,900} & \multicolumn{2}{|c|}{1,700} \\
\hline Wet season & \multicolumn{2}{|c|}{ Nov-May } & \multicolumn{2}{|c|}{ Oct-Apr } \\
\hline Farm property & \multicolumn{2}{|c|}{ Paraíso farm } & $\begin{array}{c}\text { Rancho do Sol } \\
\text { farm }\end{array}$ & Gianetta farm \\
\hline Coordinates & $\begin{array}{l}7.032^{\circ} \mathrm{S}, \\
55.363^{\circ} \mathrm{W}\end{array}$ & $\begin{array}{l}7.023^{\circ} \mathrm{S} \\
55.375^{\circ} \mathrm{W}\end{array}$ & $\begin{array}{l}15.797^{\circ} \mathrm{S}, \\
55.332^{\circ} \mathrm{W}\end{array}$ & $\begin{array}{l}15.805^{\circ} \mathrm{S} \\
55.336^{\circ} \mathrm{W}\end{array}$ \\
\hline
\end{tabular}

Soil classification

(IUSS Working Group

WRB, 2015, and Soil

Lixisols, Oxisols $\quad$ Arenosols, Entisols Quartzipsamments

Survey Staff, 2014)

\begin{tabular}{ccccc}
\hline $\begin{array}{c}\text { Predominant land } \\
\text { cover }\end{array}$ & Rainforest & Pasture & $\begin{array}{c}\text { Cerrado sensu } \\
\text { stricto }\end{array}$ & Pasture \\
\hline Aspect & & E-W & \\
\hline Average slope (\%) & 23.6 & 7.5 & 8.4 & 8.7 \\
\hline $\begin{array}{c}\text { Average elevation (m, } \\
\text { above mean sea level) }\end{array}$ & 292.4 & 223.0 & 811.1 & \\
\hline
\end{tabular}


Table 2. Mean, one standard deviation and sample size (n) of soil physical and chemical properties.

\section{Amazonian catchments}

\begin{tabular}{|c|c|c|c|c|}
\hline $\begin{array}{c}\text { Soil } \\
\text { properties }\end{array}$ & AFOR & APAS & CCER & CPAS \\
\hline Sand (\%) & $67.2 \pm 6.0(8)$ & $57.6 \pm 6.4(8)$ & $81.1 \pm 20.5(6)$ & $93.3 \pm 1.0(8)$ \\
\hline Silt (\%) & $9.1 \pm 3.9(8)$ & $22.8 \pm 6.0(8)$ & $6.1 \pm 7.3(6)$ & $1.5 \pm 0.4(8)$ \\
\hline Clay (\%) & $23.7 \pm 6.1(8)$ & $19.6 \pm 5.5(8)$ & $14.0 \pm 13.4(6)$ & $5.2 \pm 0.7(8)$ \\
\hline $\mathrm{pH}$ & $5.7 \pm 0.3(3)^{a}$ & $6.4 \pm 0.7(3)^{a}$ & $3.6 \pm 0.3(6)^{c}$ & $4.4 \pm 0.5(8)^{d}$ \\
\hline C (\%) & $3.19 \pm 2.54(5)^{\mathrm{a}}$ & $1.47 \pm 0.45(6)^{a}$ & $3.41 \pm 3.88(6)^{c}$ & $1.33 \pm 1.01(8)^{\mathrm{c}}$ \\
\hline N (\%) & $0.27 \pm 0.22(5)^{\mathrm{a}}$ & $0.12 \pm 0.04(6)^{a}$ & $0.18 \pm 0.20(6)^{c}$ & $0.07 \pm 0.05(8)^{c}$ \\
\hline C:N ratio & $11.9 \pm 1.8$ & $11.8 \pm 0.5$ & $17.9 \pm 2.4$ & $18.3 \pm 3.3$ \\
\hline Al $\left(\mathrm{g} \mathrm{kg}^{-1}\right)$ & $57.8 \pm 16.3(8)^{a}$ & $43.1 \pm 19.2(8)^{a}$ & $26.5 \pm 23.4(6)^{c}$ & $16.1 \pm 3.4(8)^{c}$ \\
\hline $\mathrm{Ca}\left(\mathrm{g} \mathrm{kg}^{-1}\right)$ & $1.0 \pm 0.6(8)^{a}$ & $0.5 \pm 0.2(8)^{a}$ & $<0.1 \pm<0.1(6)^{c}$ & $0.2 \pm 0.1(8)^{d}$ \\
\hline $\mathrm{Fe}\left(\mathrm{g} \mathrm{kg}^{-1}\right)$ & $15.5 \pm 6.1(8)^{a}$ & $11.5 \pm 6.8(8)^{a}$ & $10.8 \pm 4.6(6)^{c}$ & $13.2 \pm 6.8(8)^{c}$ \\
\hline$K\left(\mathbf{g ~ k g}^{-1}\right)$ & $3.0 \pm 2.2(8)^{\mathrm{a}}$ & $5.6 \pm 3.4(8)^{b}$ & $1.0 \pm 1.4(6)^{c}$ & $0.1 \pm<0.1(8)^{c}$ \\
\hline 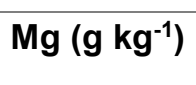 & $0.4 \pm 0.2(8)^{a}$ & $0.8 \pm 0.5(8)^{b}$ & $0.1 \pm 0.2(6)^{c}$ & $0.1 \pm 0.1(8)^{c}$ \\
\hline $\operatorname{Mn}\left(\mathrm{g} \mathrm{kg}^{-1}\right)$ & $0.8 \pm 1.0(8)^{a}$ & $0.2 \pm 0.2(8)^{b}$ & $<0.1 \pm<0.1(6)^{c}$ & $<0.1 \pm<0.1(8)^{\mathrm{c}}$ \\
\hline 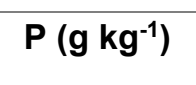 & $0.2 \pm 0.1(8)^{a}$ & $0.2 \pm 0.1(8)^{a}$ & $0.2 \pm 0.2(6)^{c}$ & $0.1 \pm<0.1(8)^{c}$ \\
\hline $\mathbf{S}\left(\mathrm{g} \mathrm{kg}^{-1}\right)$ & $0.2 \pm 0.1(8)^{a}$ & $0.2 \pm 0.1(8)^{\mathrm{a}}$ & $0.2 \pm 0.2(6)^{c}$ & $0.1 \pm<0.1(8)^{\mathrm{c}}$ \\
\hline
\end{tabular}

Significant differences $(p<.05)$ are indicated by different letters. Comparisons were performed between catchments within the same biome. 
2 Table 3. Correlations between variables and components after varimax rotation.

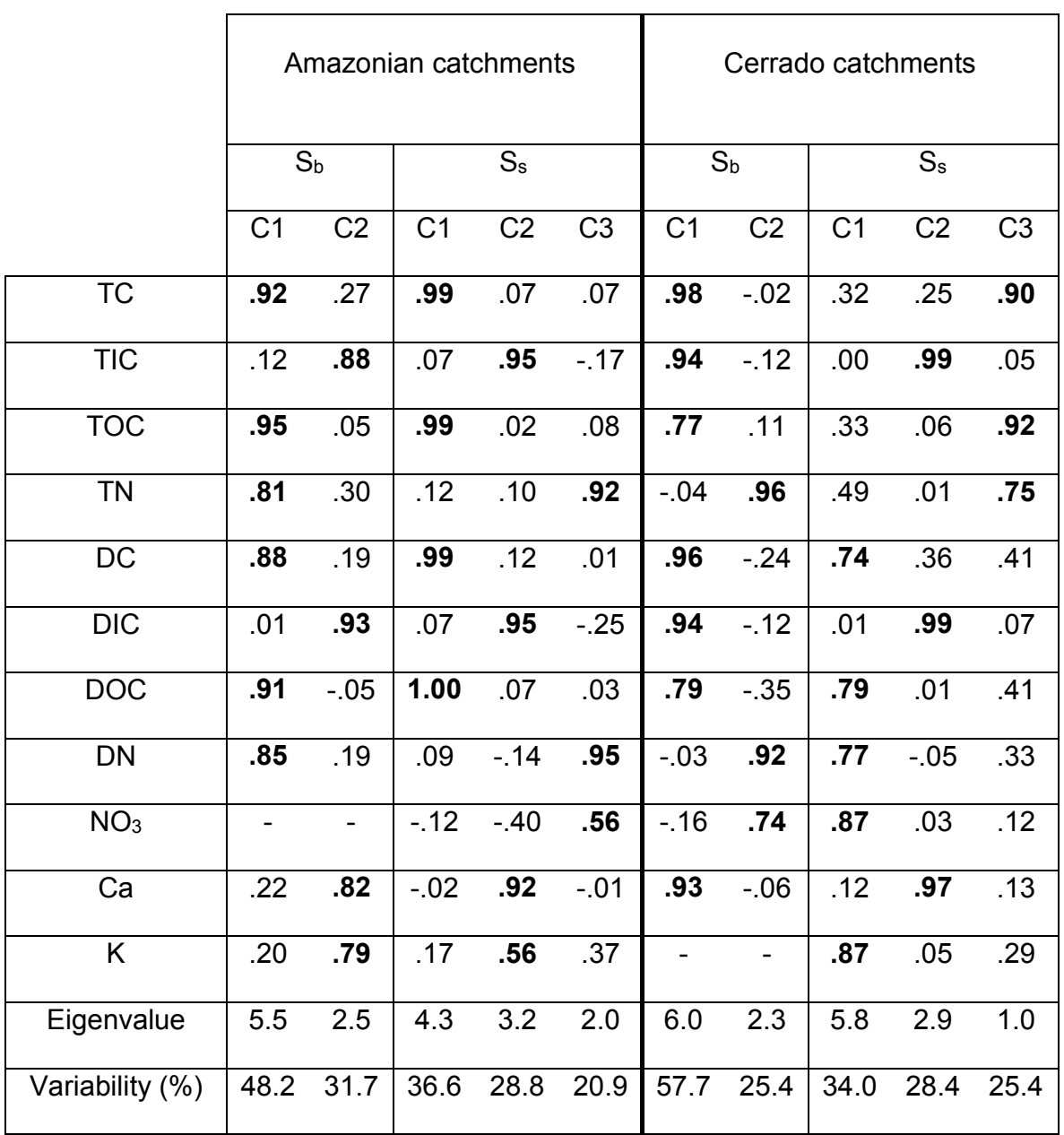


1 Table 4. Base streamflow, storm streamflow and total streamflow ratios of stream output fluxes for each pair of catchments.

\begin{tabular}{|c|c|c|c|c|c|c|c|c|c|c|}
\hline Ratio & Flow type & TOC & TIC & TN & DOC & DIC & DN & $\mathrm{NO}_{3}$ & $\mathrm{Ca}$ & $\mathbf{K}$ \\
\hline APAS:AFOR & Base streamflow & 2.8 & 5.0 & 3.4 & 2.3 & 4.5 & 2.8 & 3.9 & 3.6 & 4.1 \\
\hline APAS:AFOR & Storm streamflow & 5.8 & 5.0 & 4.7 & 5.8 & 4.8 & 4.4 & 3.8 & 4.6 & 5.7 \\
\hline APAS:AFOR & Total streamflow & 3.6 & 5.0 & 3.7 & 3.2 & 4.6 & 3.2 & 3.9 & 3.8 & 4.4 \\
\hline CPAS:CCER & Base streamflow & 1.8 & 1.5 & 3.3 & 1.2 & 0.4 & 4.0 & 3.8 & 1.8 & 6.8 \\
\hline CPAS:CCER & Storm streamflow & 1.0 & 0.7 & 1.2 & 1.1 & 0.6 & 1.7 & 2.7 & 2.8 & 1.4 \\
\hline CPAS:CCER & Total streamflow & 1.6 & 1.4 & 3.0 & 1.2 & 0.4 & 3.7 & 3.7 & 1.8 & 5.5 \\
\hline
\end{tabular}

3 
1 Table 5. Percentage ratio of the storm streamflow duration, volume and fluxes to the total streamflow.

$\mathrm{S}_{\mathrm{s}}: \mathrm{S}_{\mathrm{t}}$ (CAN fluxes)

\begin{tabular}{|c|c|c|c|c|c|c|c|c|c|c|c|}
\hline Catchment & $\begin{array}{c}\mathrm{S}_{\mathrm{s}}: \mathrm{S}_{\mathrm{t}} \\
\text { (duration) }\end{array}$ & $\begin{array}{c}\mathrm{S}_{\mathrm{s}}: \mathrm{S}_{\mathrm{t}} \\
\text { (volume) }\end{array}$ & TOC & $\mathrm{TIC}$ & $\mathrm{TN}$ & DOC & DIC & DN & $\mathrm{NO}_{3}$ & $\mathrm{Ca}$ & $\mathrm{K}$ \\
\hline AFOR & $4.9 \%$ & $15.9 \%$ & $26 \%$ & $24 \%$ & $23 \%$ & $28 \%$ & $31 \%$ & $23 \%$ & $7 \%$ & $29 \%$ & $23 \%$ \\
\hline APAS & $5.3 \%$ & $26.5 \%$ & $42 \%$ & $23 \%$ & $28 \%$ & $50 \%$ & $33 \%$ & $32 \%$ & $7 \%$ & $34 \%$ & $30 \%$ \\
\hline CCER & $2.0 \%$ & $5.2 \%$ & $26 \%$ & $3 \%$ & $14 \%$ & $18 \%$ & $6 \%$ & $12 \%$ & $4 \%$ & $2 \%$ & $24 \%$ \\
\hline CPAS & $1.6 \%$ & $2.8 \%$ & $16 \%$ & $2 \%$ & $6 \%$ & $17 \%$ & $10 \%$ & $6 \%$ & $3 \%$ & $2 \%$ & $6 \%$ \\
\hline
\end{tabular}

3

4 
Table A.1. Descriptive statistics of the base streamflow hydrochemistry ${ }^{a}$.

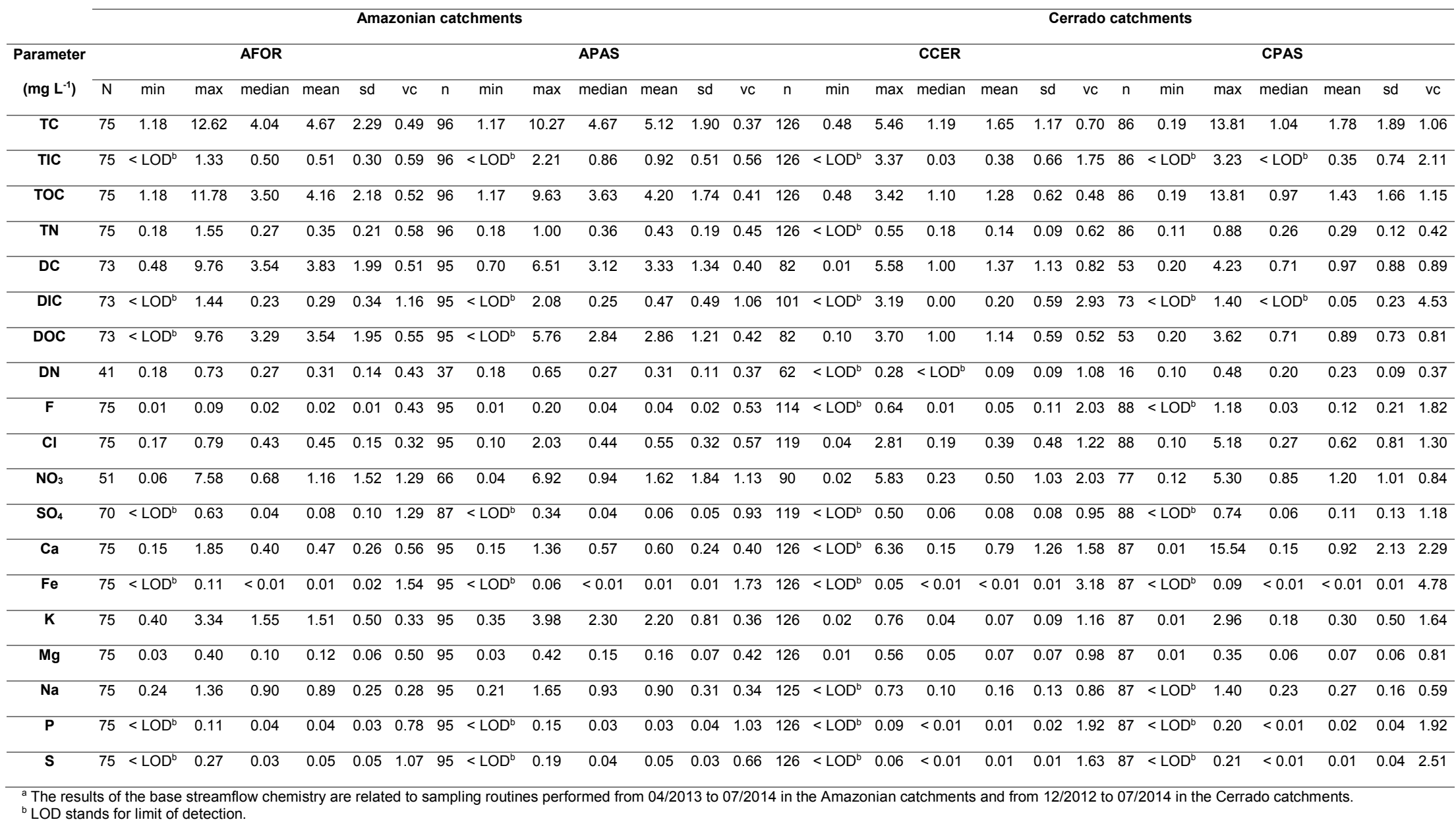


Table A.2. Descriptive statistics of the storm streamflow hydrochemistrya

\begin{tabular}{|c|c|c|c|c|c|c|c|c|c|c|c|c|c|c|c|c|c|c|c|c|c|c|c|c|c|c|c|c|}
\hline \multirow{3}{*}{$\begin{array}{c}\text { Parameter } \\
\left(\mathrm{mg} \mathrm{L}^{-1}\right)\end{array}$} & \multicolumn{14}{|c|}{ Amazonian catchments } & \multicolumn{14}{|c|}{ Cerrado catchments } \\
\hline & \multicolumn{7}{|c|}{ AFOR } & \multicolumn{7}{|c|}{ APAS } & \multicolumn{7}{|c|}{ CCER } & \multicolumn{7}{|c|}{ CPAS } \\
\hline & $\mathrm{n}$ & $\min$ & $\max$ & median & mean & $\mathrm{sd}$ & vc & $\mathrm{n}$ & $\min$ & $\max$ & median & mean & sd & $\mathrm{vc}$ & $n$ & $\min$ & $\max$ & median & mean & $\mathrm{sd}$ & vc & $\mathrm{n}$ & $\min$ & $\max$ & median & mean & sd & vc \\
\hline TC & 108 & 1.56 & 25.80 & 6.08 & 7.39 & 4.91 & 0.66 & 160 & 2.63 & 96.80 & 7.04 & 8.59 & 9.71 & 1.13 & 119 & 0.77 & 24.90 & 3.57 & 4.27 & 3.16 & 0.74 & 43 & 0.50 & 20.02 & 7.00 & 7.47 & 3.98 & 0.53 \\
\hline TIC & 108 & 0.08 & 2.20 & 0.35 & 0.53 & 0.47 & 0.87 & 160 & $<\mathrm{LOD}^{\mathrm{b}}$ & 2.70 & 0.52 & 0.64 & 0.49 & 0.76 & 119 & $<L^{2} D^{b}$ & 3.79 & $<L^{2} D^{b}$ & 0.17 & 0.58 & 3.44 & 43 & $<\mathrm{LOD}^{\mathrm{b}}$ & 4.00 & 0.08 & 0.64 & 1.11 & 1.73 \\
\hline TOC & 108 & 1.38 & 25.01 & 5.50 & 6.86 & 4.81 & 0.70 & 160 & 2.63 & 95.50 & 6.29 & 7.95 & 9.66 & 1.21 & 119 & 0.77 & 23.10 & 3.47 & 4.10 & 3.00 & 0.73 & 43 & 0.50 & 18.27 & 6.50 & 6.84 & 3.88 & 0.56 \\
\hline TN & 108 & 0.18 & 1.82 & 0.40 & 0.46 & 0.24 & 0.53 & 160 & 0.22 & 1.30 & 0.50 & 0.49 & 0.17 & 0.35 & 119 & 0.10 & 1.50 & 0.27 & 0.27 & 0.18 & 0.65 & 43 & 0.20 & 3.10 & 0.50 & 0.61 & 0.48 & 0.79 \\
\hline DC & 93 & 1.94 & 27.30 & 5.35 & 6.73 & 4.41 & 0.65 & 148 & 1.12 & 98.60 & 5.18 & 6.94 & 10.58 & 1.52 & 119 & 0.80 & 10.20 & 2.90 & 3.26 & 1.73 & 0.53 & 38 & 3.30 & 11.40 & 6.21 & 6.50 & 1.96 & 0.30 \\
\hline DIC & 46 & $<\operatorname{LOD}^{b}$ & 2.10 & 0.34 & 0.52 & 0.56 & 1.06 & 125 & $<\mathrm{LOD}^{\mathrm{b}}$ & 2.60 & 0.30 & 0.45 & 0.51 & 1.14 & 115 & $<\mathrm{LOD}^{\mathrm{b}}$ & 2.25 & $<\mathrm{LOD}^{\mathrm{b}}$ & 0.12 & 0.40 & 3.43 & 41 & $<\mathrm{LOD}^{\mathrm{b}}$ & 3.90 & $<\mathrm{LOD}^{\mathrm{b}}$ & 0.62 & 1.10 & 1.75 \\
\hline DOC & 93 & 1.21 & 26.30 & 4.87 & 6.13 & 4.33 & 0.70 & 148 & 1.12 & 97.60 & 4.73 & 6.47 & 10.49 & 1.61 & 119 & 0.80 & 8.22 & 2.80 & 3.13 & 1.62 & 0.51 & 38 & 2.10 & 10.90 & 5.45 & 5.81 & 2.03 & 0.34 \\
\hline DN & 91 & 0.18 & 1.46 & 0.36 & 0.42 & 0.23 & 0.55 & 117 & 0.27 & 0.90 & 0.40 & 0.42 & 0.15 & 0.34 & 65 & $<L^{\prime} O D^{b}$ & 0.91 & 0.18 & 0.22 & 0.11 & 0.49 & 35 & 0.10 & 2.10 & 0.40 & 0.49 & 0.37 & 0.75 \\
\hline $\mathrm{F}$ & 109 & 0.01 & 3.62 & 0.02 & 0.07 & 0.35 & 5.03 & 159 & 0.01 & 0.10 & 0.03 & 0.03 & 0.01 & 0.42 & 119 & $<\mathrm{LOD}^{\mathrm{b}}$ & 0.33 & 0.01 & 0.01 & 0.03 & 2.93 & 36 & $<\mathrm{LOD}^{\mathrm{b}}$ & 1.23 & 0.04 & 0.19 & 0.30 & 1.51 \\
\hline Cl & 109 & 0.35 & 16.05 & 0.53 & 0.81 & 1.53 & 1.88 & 159 & 0.08 & 4.95 & 0.60 & 0.63 & 0.40 & 0.64 & 119 & 0.06 & 4.20 & 0.17 & 0.28 & 0.42 & 1.50 & 36 & 0.20 & 3.65 & 0.59 & 0.93 & 0.90 & 0.96 \\
\hline $\mathrm{NO}_{3}$ & 107 & 0.10 & 6.66 & 0.44 & 0.93 & 1.21 & 1.29 & 142 & 0.01 & 7.56 & 0.40 & 1.18 & 1.74 & 1.48 & 109 & $<L^{\prime} O D^{b}$ & 6.53 & 0.34 & 1.09 & 1.62 & 1.48 & 35 & 0.27 & 3.20 & 1.00 & 1.02 & 0.50 & 0.48 \\
\hline $\mathrm{SO}_{4}$ & 107 & 0.01 & 1.03 & 0.07 & 0.12 & 0.16 & 1.26 & 159 & 0.01 & 0.55 & 0.07 & 0.09 & 0.07 & 0.82 & 117 & 0.02 & 0.62 & 0.05 & 0.07 & 0.07 & 0.97 & 36 & 0.04 & 0.38 & 0.11 & 0.14 & 0.09 & 0.67 \\
\hline $\mathrm{Ca}$ & 109 & 0.22 & 2.65 & 0.48 & 0.70 & 0.53 & 0.77 & 160 & 0.09 & 3.71 & 0.47 & 0.61 & 0.54 & 0.88 & 118 & 0.06 & 5.30 & 0.17 & 0.41 & 0.84 & 2.02 & 42 & 0.08 & 7.18 & 0.45 & 1.43 & 1.88 & 1.30 \\
\hline $\mathrm{Fe}$ & 109 & $<\operatorname{LOD}^{b}$ & 0.06 & 0.01 & 0.01 & 0.02 & 1.04 & 160 & $<\mathrm{LOD}^{\mathrm{b}}$ & 0.23 & 0.03 & 0.03 & 0.03 & 1.02 & 119 & $<L^{\prime} O D^{b}$ & 0.11 & 0.01 & 0.02 & 0.02 & 1.09 & 42 & $<L^{2} D^{b}$ & 0.05 & $<0.01$ & 0.01 & 0.02 & 1.75 \\
\hline K & 109 & 0.91 & 3.62 & 1.87 & 1.96 & 0.46 & 0.23 & 160 & 0.31 & 4.11 & 2.51 & 2.54 & 0.53 & 0.21 & 118 & 0.02 & 1.68 & 0.16 & 0.23 & 0.23 & 0.98 & 42 & 0.15 & 2.80 & 0.50 & 0.60 & 0.45 & 0.73 \\
\hline Mg & 109 & 0.04 & 0.30 & 0.12 & 0.14 & 0.06 & 0.40 & 160 & 0.02 & 0.26 & 0.12 & 0.14 & 0.05 & 0.35 & 118 & 0.03 & 2.36 & 0.08 & 0.12 & 0.22 & 1.81 & 42 & 0.04 & 0.42 & 0.08 & 0.11 & 0.07 & 0.65 \\
\hline $\mathrm{Na}$ & 109 & 0.56 & 1.95 & 0.92 & 0.96 & 0.22 & 0.23 & 160 & 0.14 & 1.18 & 0.76 & 0.72 & 0.23 & 0.33 & 118 & 0.05 & 1.57 & 0.11 & 0.22 & 0.22 & 1.01 & 42 & 0.15 & 1.62 & 0.27 & 0.41 & 0.30 & 0.72 \\
\hline$P$ & 109 & $<\operatorname{LOD}^{b}$ & 0.11 & $<\operatorname{LOD}^{b}$ & 0.02 & 0.03 & 1.45 & 160 & $<\operatorname{LOD}^{b}$ & 0.14 & 0.01 & 0.04 & 0.04 & 1.13 & 119 & $<\operatorname{LOD}^{b}$ & 0.11 & $<0.01$ & 0.02 & 0.03 & 1.39 & 42 & $<\operatorname{LOD}^{b}$ & 0.09 & $<0.01$ & 0.02 & 0.03 & 1.82 \\
\hline S & 109 & $<L^{\prime} O D^{b}$ & 0.52 & 0.05 & 0.07 & 0.08 & 1.18 & 160 & $<\operatorname{LOD}^{b}$ & 0.21 & 0.07 & 0.07 & 0.05 & 0.78 & 119 & $<\operatorname{LOD}^{b}$ & 0.26 & 0.02 & 0.03 & 0.03 & 1.18 & 42 & $<L^{\prime} O D^{b}$ & 0.09 & $<0.01$ & 0.01 & 0.03 & 1.76 \\
\hline
\end{tabular}

a The results of the storm streamflow chemistry are related to sampling obtained from 02/2013 to 02/2014 in the Amazon and Cerrado catchments.

${ }^{\mathrm{b}} \mathrm{LOD}$ stands for limit of detection. 